\title{
Where there is smoke there is mercury: Assessing boreal forest fire mercury emissions using aircraft and highlighting uncertainties associated with upscaling emissions estimates
}

\author{
David S. McLagan ${ }^{1,2}$, Geoff W. Stupple ${ }^{1}$, Andrea Darlington ${ }^{1}$, Katherine Hayden ${ }^{1}$, and Alexandra Steffen ${ }^{1}$ \\ ${ }^{1}$ Air Quality Research Division (ARQD), Environment and Climate Change Canada, \\ 4905 Dufferin St, North York, ON M3H 5T4, Canada \\ ${ }^{2}$ Dept. Environmental Geochemistry, Institute for Geoecology, Technical University of Braunschweig, \\ Langer Kamp 19c, 38106 Braunschweig, Germany
}

Correspondence: Alexandra Steffen (alexandra.steffen@canada.ca)

Received: 26 October 2020 - Discussion started: 6 November 2020

Revised: 25 February 2021 - Accepted: 27 February 2021 - Published: 14 April 2021

\begin{abstract}
Emissions from biomass burning are an important source of mercury $(\mathrm{Hg})$ to the atmosphere and an integral component of the global $\mathrm{Hg}$ biogeochemical cycle. In 2018, measurements of gaseous elemental Hg (GEM) were taken on board a research aircraft along with a series of coemitted contaminants in the emissions plume of an $88 \mathrm{~km}^{2}$ boreal forest wildfire on the Garson Lake Plain (GLP) in NW Saskatchewan, Canada. A series of four flight tracks were made perpendicular to the plume at increasing distances from the fire, each with three to five passes at different altitudes at each downwind location. The maximum GEM concentration measured on the flight was $2.88 \mathrm{ng} \mathrm{m}^{-3}$, which is $\approx 2.4 \times$ background concentration. GEM concentrations were significantly correlated with the co-emitted carbon species (CO, $\mathrm{CO}_{2}$, and $\mathrm{CH}_{4}$ ). Emissions ratios (ERs) were calculated from measured GEM and carbon co-contaminant data. Using the most correlated (least uncertain) of these ratios (GEM : CO), GEM concentrations were estimated at the higher $0.5 \mathrm{~Hz}$ time resolution of the $\mathrm{CO}$ measurements, resulting in maximum GEM concentrations and enhancements of $6.76 \mathrm{ng} \mathrm{m}^{-3}$ and $\approx 5.6 \times$, respectively. Extrapolating the estimated maximum $0.5 \mathrm{~Hz}$ GEM concentration data from each downwind location back to source, $1 \mathrm{~km}$ and $1 \mathrm{~m}$ (from fire) concentrations were predicted to be 12.9 and $30.0 \mathrm{ng} \mathrm{m}^{-3}$, or enhancements of $\approx 11 \times$ and $\approx 25 \times$, respectively. ERs and emissions factors (EFs) derived from the measured data and literature values were also used to calculate $\mathrm{Hg}$ emissions estimates on three spatial scales: (i) the GLP fires themselves, (ii) all bo-
\end{abstract}

real forest biomass burning, and (iii) global biomass burning. The most robust estimate was of the GLP fires $(21 \pm 10 \mathrm{~kg}$ of $\mathrm{Hg}$ ) using calculated EFs that used minimal literaturederived data. Using the Top-down Emission Rate Retrieval Algorithm (TERRA), we were able to determine a similar emission estimate of $22 \pm 7 \mathrm{~kg}$ of $\mathrm{Hg}$. The elevated uncertainties of the other estimates and high variability between the different methods used in the calculations highlight concerns with some of the assumptions that have been used in calculating $\mathrm{Hg}$ biomass burning in the literature. Among these problematic assumptions are variable ERs of contaminants based on vegetation type and fire intensity, differing atmospheric lifetimes of emitted contaminants, the use of only one co-contaminant in emissions estimate calculations, and the paucity of atmospheric $\mathrm{Hg}$ species concentration measurements in biomass burning plumes.

\section{Introduction}

A number of studies have provided evidence that mercury $(\mathrm{Hg})$ - a persistent, bioaccumulative, and toxic contaminant - is emitted during biomass burning (e.g. Friedli et al., 2003a, b; Obrist et al., 2008; Chen et al., 2013). Emissions of $\mathrm{Hg}$ from biomass burning demonstrate one of the similarities between anthropogenically perturbed carbon and $\mathrm{Hg}$ biogeochemical cycles. The active pools of these elements in their respective biogeochemical cycles have been augmented by 
emissions from anthropogenic activities such as mining and industry. Similar to carbon, plant biomass also represents a significant global sink of mercury emitted to the atmosphere. The major mechanism of $\mathrm{Hg}$ uptake to plants is the inspiration of gaseous elemental $\mathrm{Hg}$ (GEM, the dominant form of atmospheric $\mathrm{Hg}$ ) via leaf stomata (Rea et al., 2001; Laacouri et al., 2013; Jiskra et al., 2015). While it was thought this process resulted in oxidation of the GEM taken up via leaf stomata leading to a relatively unidirectional flux (Demers et al., 2013; Jiskra et al., 2015), a recent study using stable $\mathrm{Hg}$ isotopes suggests reduction and reemission of this internal leaf $\mathrm{Hg}$ (between 29 and $42 \%$ of gross uptake based on the plant species studied) may occur (Yuan et al., 2018). The retained $\mathrm{Hg}$ in leaf matter associated with this uptake mechanism is eventually deposited to the ground in litterfall and either added to the pool of $\mathrm{Hg}$ in the soil or reemitted to the atmosphere during decomposition of the plant material (St. Louis et al., 2001; Demers et al., 2007, 2013).

Other possible uptake mechanisms of $\mathrm{Hg}$ to plant biomass have been considered and discussed in the literature. While gaseous oxidised $\mathrm{Hg}(\mathrm{GOM})$ and particulate-bound $\mathrm{Hg}$ (PBM) can deposit to plant surfaces, in particular leaves, it has been suggested that this is not a stable sorptive process. Deposited Hg can be photo-reduced to GEM and reemitted to the atmosphere (Graydon et al., 2006; Mowat et al., 2011; Demers et al., 2013) or washed off and deposited to soils by precipitation throughfall (Rea et al., 2000, 2001; Demers et al., 2007, 2013). It is also possible that plants can take up $\mathrm{Hg}$ from the soil via their roots (Godbold et al., 1988; St. Louis et al., 2001; Graydon et al., 2009). However, this process has been shown to contribute little to the accumulated $\mathrm{Hg}$ in biomass except in soils heavily contaminated with $\mathrm{Hg}$ (Lindberg et al., 1979; Graydon et al., 2009; Mowat et al., 2011).

The high volatility of elemental $\mathrm{Hg}$ (Ariya et al., 2015) and the conversion of oxidised forms of $\mathrm{Hg}$ to elemental $\mathrm{Hg}$ at temperatures generated in biomass burning (Biester and Scholz, 1996) result in $\mathrm{Hg}$ stored in biomass being released to the atmosphere during biomass burning. Emissions of $\mathrm{Hg}$ from biomass burning are predominantly in the form of GEM (Friedli et al., 2003a; Finley et al., 2009; De Simone et al., 2017). Emissions of GOM have not been detected from controlled or wildfire biomass burning plumes (Friedli et al., 2003a; Obrist et al., 2008; Finley et al., 2009; Chen et al., 2013). Nonetheless, GOM measurements have a lower temporal resolution and high inherent uncertainty (Finley et al., 2009; De Simone et al., 2017), and more measurements using a range of analysis methods are required to confirm this assessment. A key factor driving this uncertainty is the likelihood that GOM will partition to particles due to their elevated concentrations in biomass burning plumes (Obrist et al., 2008). While measurements of PBM are again uncertain due to differing methods, long sampling times, and other sampling artefacts (De Simone et al., 2017), emissions of PBM have been reported to contribute between 3.8 and $15 \%$ to total atmospheric $\mathrm{Hg}$ (TAM) emissions in wildfires
(Friedli et al., 2001, 2003a, b; Finley et al., 2009; Chen et al., 2013) and from $<1 \%$ to $48 \%$ in controlled laboratory burns (Friedli et al., 2001, 2003a; Obrist et al., 2008). The proportion of PBM likely increases with increasing biomass moisture content (Obrist et al., 2008).

The proportion of stored $\mathrm{Hg}$ in biomass released to the atmosphere during combustion has been tested using a mass balance approach in controlled laboratory burns and is generally considered complete ( $>94 \%$ ), regardless of species (Friedli et al., 2001, 2003a; Obrist et al., 2008). However, studies utilising controlled laboratory burns consider only releases from burned living plant biomass and litterfall and are likely to underestimate actual emissions from wildfires that additionally include $\mathrm{Hg}$ released from underlying soils associated with soil heating (Friedli et al., 2003a). While large uncertainties remain as to the amount of $\mathrm{Hg}$ that is released from soils, DeBano (2000) reported that temperatures can reach $850^{\circ} \mathrm{C}$ at the litter-soil interface in loworganic-content soils, but this rapidly decreases to approximately $150{ }^{\circ} \mathrm{C}$ at only $5 \mathrm{~cm}$ below the surface in dry soils. This suggests that $\mathrm{Hg}$ releases from soils are limited to the upper soil horizons (primarily the organic horizon; Engle et al., 2006; Biswas et al., 2008), where temperatures are likely to be sufficient $\left(\geq 300^{\circ} \mathrm{C}\right)$ to release at least a portion of, if not all, $\mathrm{Hg}$ complexed in soil organic matter (Biester and Scholz, 1996). Thus, Hg releases from soil are more likely to contribute an increased proportion of emissions in temperate and boreal forests, in which $>90 \%$ of total $\mathrm{Hg}$ in forest ecosystems can be contained in soil organic matter (Schwesig and Matzner, 2000; Friedli et al., 2007; Obrist, 2012).

While a number of studies have made atmospheric $\mathrm{Hg}$ measurements in biomass burning plumes, the majority of these studies have been based on measurements made at substantial distances from the fires themselves either at groundbased monitoring stations (Brunke et al., 2001; Sigler et al., 2003; Weiss-Penzias et al., 2007; Finley et al., 2009) or in aircraft (Artaxo et al., 2000; Ebinghaus et al., 2007; Slemr et al., 2018). From review of the literature, two studies were found that made aircraft-based atmospheric $\mathrm{Hg}$ measurements directly in a biomass burning plume near source (within $50 \mathrm{~km}$ of a fire). Friedli et al. measured GEM and PBM in wildfires in temperate forests in northern Ontario, Canada (2003a), and northern Washington State, USA (2003b), with GEM enhancements of up to $\approx 1.4$ and 6 times background concentrations, respectively. Given carbon monoxide (CO) concentrations are enhanced relative to atmospheric $\mathrm{Hg}$ in biomass burning compared to industrial plumes (Chatfield et al., 1998; Jaffe et al., 2005; Wang et al., 2015), these and other studies have used emissions ratios (ERs) of atmospheric $\mathrm{Hg}$ concentrations to co-located measurements of $\mathrm{CO}$ and/or carbon dioxide $\left(\mathrm{CO}_{2}\right)$ concentrations to identify biomass burning plumes.

Additionally, ERs and/or emissions factors (EFs, unit mass of $\mathrm{Hg}$ released per unit mass of fuel combusted; grams per kilogram) can be used to make global biomass burn- 
ing $\mathrm{Hg}$ emissions estimates using these more widely monitored carbon constituents emitted from biomass burning plumes as surrogates. Nonetheless, upscaling emissions using co-emitted surrogates requires some large assumptions (i.e. equivalent atmospheric residence times, ERs that do not vary by burning intensity), which can introduce considerable uncertainty to these estimates (Cofer III et al., 1998; Andreae and Merlet, 2001; Andreae, 2019).

In this study, we made aircraft-based measurements of GEM and co-emitted carbon gases in a plume from a Canadian boreal forest wildfire. It is our aim to assess the magnitude of GEM emissions from this fire; to investigate ERs of GEM to $\mathrm{CO}, \mathrm{CO}_{2}$, methane $\left(\mathrm{CH}_{4}\right)$, and non-methane organic gases (NMOGs), each enhanced in biomass burning plumes; and to estimate total boreal forest and global emissions for $\mathrm{Hg}$ from biomass burning based on these data using four different upscaling methods. We also assess the validity of upscaling these emissions estimates, highlighting the uncertainties associated with these calculations.

\section{Methods}

\subsection{Site and flight descriptions}

The forest fire was situated at approximately $56.45^{\circ} \mathrm{N}$ and $109.75^{\circ} \mathrm{W}$ (425-450 ma.s.l.) on the Garson Lake Plain (GLP) between Garson Lake and Lac La Loche in northern Saskatchewan, $\approx 520 \mathrm{~km}$ NNW of Saskatoon, Canada $(\approx 400 \mathrm{~km}$ NNE of Edmonton; Fig. 1). The fire was ignited by a lightning strike and burned from 23 to 26 June 2018 , burning a total area of $\approx 88.0 \mathrm{~km}^{2}$ (a $10 \%$ uncertainty is assumed with this estimate). The total burned area $\left(88.0 \mathrm{~km}^{2}\right)$ was calculated using satellite imagery (NASA, 2020) and ArcGIS (ESRI) and can be found in the Supplement (Fig. S1.1). The area burned is part of Canada's Boreal Plains biome and is a mixed northern boreal forest likely dominated by black spruce (Picea mariana), tamarack (American larch; Larix laricina), trembling aspen (Populus tremuloides), and jack pine (Pinus banksiana) (Korejbo, 2011; Nesdoly, 2017). Other tree species - such as white spruce (Picea glauca), balsam poplar (Populus balsamifera), balsam fir (Abies balsamea), and paper birch (Betula papyrifera) - may also have been present in the forest stands burned in this fire (Korejbo, 2011; Nesdoly, 2017). Although this fire occurred close to the Alberta oil sands facilities $(\approx 100 \mathrm{~km}$ ESE of Fort McMurray, main urban centre of the oil sands operations), winds during this flight were relatively stable south-easterlies $\left(136 \pm 10^{\circ}\right)$. As such, all segments of the flight were upwind of all facilities of the Alberta oil sands, and the data should not be influenced by any emissions of $\mathrm{Hg}$ from these facilities.

Measurements of GEM, $\mathrm{CO}, \mathrm{CO}_{2}, \mathrm{CH}_{4}$, and NMOGs were made on board the National Research Council's (NRC) Convair 580 research aircraft in the plume of the GLP fire on 25 June 2018. The monitoring component of the flight occurred between 15:00 and 18:58 GMT (09:00 and 12:58 in local Mountain Daylight Time in Alberta). Analysis of the fire plumes and thermal anomalies of the MODIS satellite imagery confirms the fire peaked on 25 June 2018 (NASA, 2020). The flight comprised a number of transects at different altitudes that passed through the plume perpendicular to the plume direction to create a virtual screen. Four screens were completed at successive distances downwind of the fire source (Fig. 2). The middle of the plume was calculated to be approximately $5-20,30-45,55-70$, and $85-100 \mathrm{~km}$ from the burning fires for screens 1,2,3, and 4, respectively. Difficulties in constraining these distances relate to the multiple fires burning on the day of the monitoring flight (Fig. 2). The middle of this range was used in calculations based on these data. The number of transects for each screen was 5, 4, 4, and 3 for screens $1-4$, respectively.

A vertical spiral was flown during each screen to determine the vertical extent and structure of the plume and the height of the mixed layer. The mean wind speeds and temperatures measured at $32 \mathrm{~Hz}$ on the aircraft with a Rosemount 858 probe (see Gordon et al., 2015, for details) during the flight were $7.9 \pm 2.4 \mathrm{~m} \mathrm{~s}^{-1}$ and $20.4 \pm 4.1^{\circ} \mathrm{C}$, respectively. The closest weather station to these fires was Lac La Loche weather station $(\approx 23 \mathrm{~km}$ east of the fires on the eastern side of Lac La Loche; $56.45^{\circ} \mathrm{N}, 109.40^{\circ} \mathrm{W}$ ), and the mean hourly ground wind speed, temperature, and relative humidity measured during the flight were $4.1 \pm 2.4 \mathrm{~m} \mathrm{~s}^{-1}, 25.8 \pm 2.0^{\circ} \mathrm{C}$, and $58.0 \pm 12.0 \%$, respectively (ECCC, 2019). Daily average wind speed, temperature, relative humidity, precipitation, and fire danger determinants for the week preceding the flight at this station are provided in Sect. S2.

\subsection{Gaseous elemental mercury measurements}

The NRC's Convair 580 research aircraft was fitted with a Tekran 2537X instrument (Tekran Instruments Corporation) for measuring GEM. The system sampled GEM, and a detailed discussion of the determination of GEM as the sampled analyte is given in the Supplement (Sect. S3). General details of this instrument can be found in Cole et al. (2014). The instrument was set up for in-flight use to decrease sample time and reduce uncertainties that can arise during aircraft deployments due to pressure changes (e.g. Slemr et al., 2018); specific details pertaining to this study are as follows. A shortened analytical cycle was developed and successfully tested in the lab (no loss of instrument accuracy and precision) that used a shorter flush $(25 \mathrm{~s})$ but higher flush rate $\left(0.2 \mathrm{~L} \mathrm{~min}^{-1}\right)$ along with shortened cartridge heat times $(15 \mathrm{~s})$ and cooling time ( $30 \mathrm{~s})$. This shortened analytical timing allowed for a shorter sample time of 2 min with a system flow rate of $1.5 \mathrm{~L} \mathrm{~min}^{-1}$ to give a measured sample volume of $3 \mathrm{~L}$. To avoid changes in pressure affecting the cell flow, a pressure controller was used on the cell vent and maintained at a constant pressure slightly above ambient ground pressure. Am- 


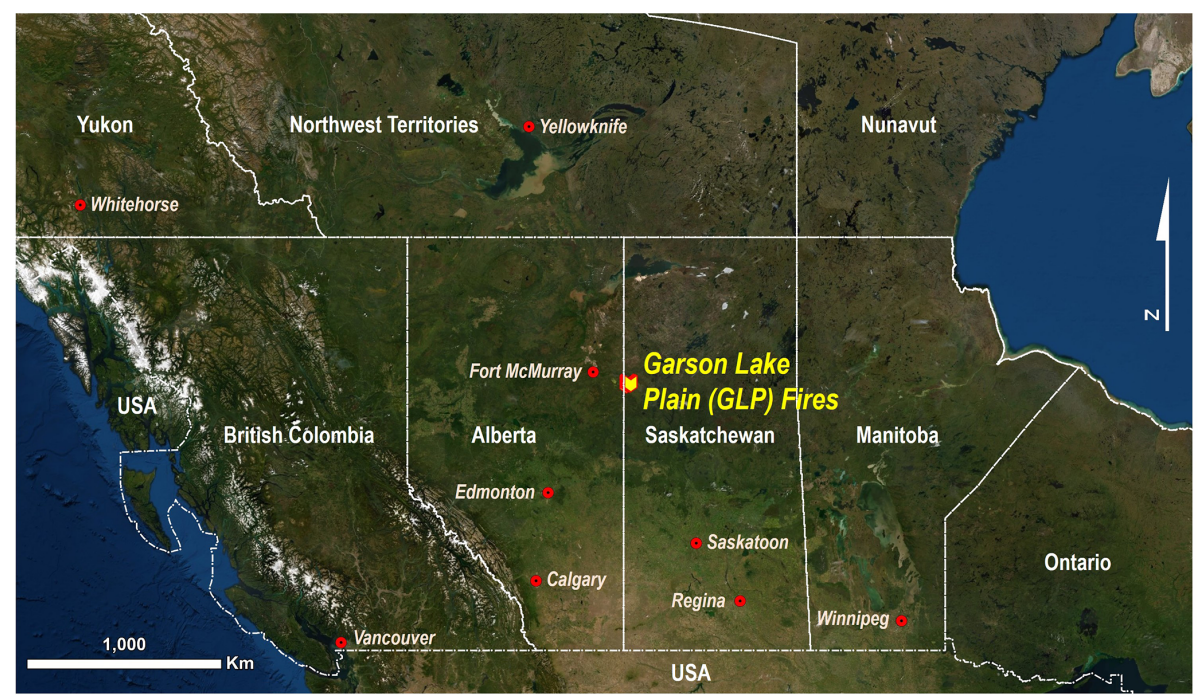

Figure 1. Regional map showing Garson Lake Plain (GLP) fires' location in northern Saskatchewan, Canada, Canadian provinces (white dashed lines), and major/relevant cities (red dots) (ArcGIS; ESRI).

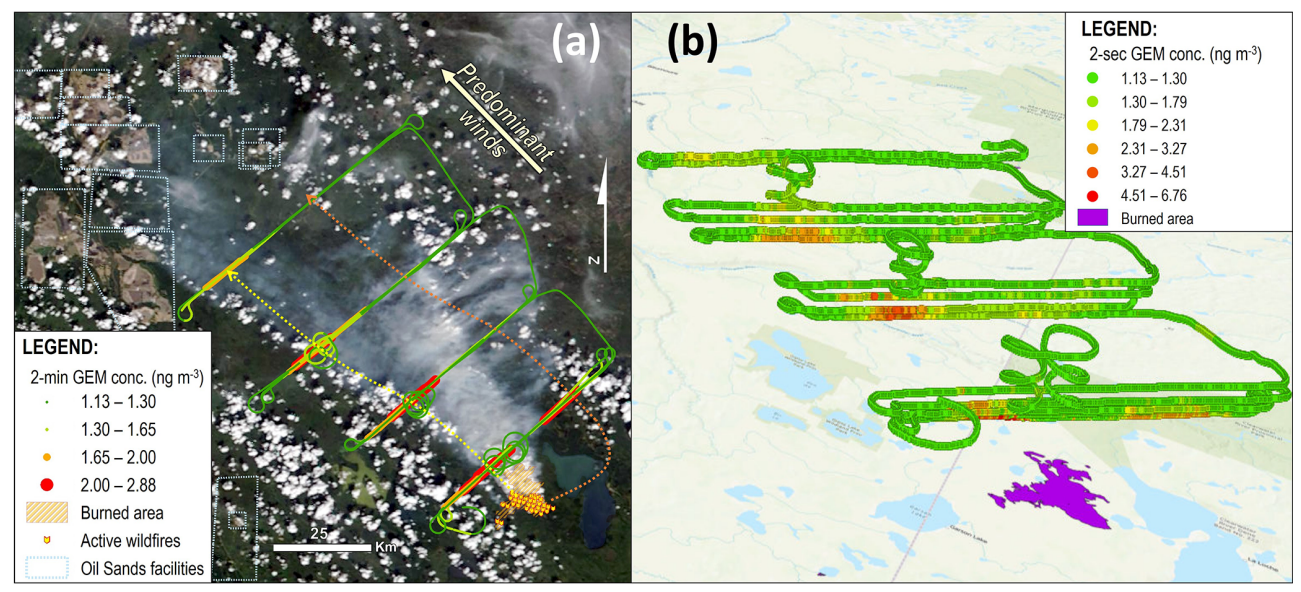

Figure 2. Panel (a) shows the 2 min measured GEM concentrations along the flight track, overlaid onto the satellite image of the wildfire taken from MODIS satellites at approximately 18:59 GMT on 25 June 2018 (near end of flight) (NASA, 2020). Yellow and orange dotted lines in panel (a) show approximate path of the south and north plumes, respectively. Panel (b) shows the $2 \mathrm{~s}$ GEM concentration calculated by conversion of the $0.5 \mathrm{~Hz}$ CO data using the GEM : CO emissions ratio (ER) along the flight path in three dimensions (ArcGIS, ESRI).

bient air was drawn in through a rear-facing inlet (to prevent particles entering the inlet) mounted on the roof of the aircraft. This inlet incorporated a bypass system that flooded the inlet with "zero" air generated by a series of three activatedcarbon filters into the instrument during take-off and landing to prevent contamination. The inlet line was $5.44 \mathrm{~m}$ in length from the inlet to the instrument and made from PTFE with an inside diameter of $2.5 \mathrm{~mm}$. Along with sampling lines for other gaseous species, this was heated to $50{ }^{\circ} \mathrm{C}$ for the first $4.5 \mathrm{~m}$ to prevent moisture from condensing within the sampling line. The remaining unheated sampling line incorporated a soda-lime trap fitted at each end with cleaned quartz wool to remove water vapour and acidic gases, as well the standard Tekran 2537 series filter pack containing a $0.25 \mu \mathrm{m}$ Teflon filter.

The system ran for a period of $>72 \mathrm{~h}$ both before and after the flight to ensure the system was at its optimal stability. During this time, the system sampled $\mathrm{Hg}$ mercury-free air generated by a Tekran 1100 zero-air generator (Tekran Instruments Corporation). Approximately $2 \mathrm{~h}$ before take-off, a series of three $55.7 \mathrm{pg} \mathrm{Hg}$ additions from the internal permeation unit of the system were made on each of the two gold amalgamation traps (additions every third sample). The additions equated to a GEM concentration of $18.57 \mathrm{ng} \mathrm{m}^{-3}$ in a $3 \mathrm{~L}$ sample. This process was again repeated after the flight. These additions function in the same way as the normal Tekran $2537 \mathrm{X}$ calibrations and were used to calibrate 
the system for the flight. The measured concentration for any given sample was adjusted using a linear adjustment based on the mean of the additions for each trap before and after the flight proportional to when the sample was taken within the flight according to Eq. (1):

$C_{i}=Z_{i} /\left[Y_{i}-\left(Y_{i}-X_{i}\right) \cdot\left(\frac{A}{B}\right)\right]$,

where $C_{i}$ is the reported GEM concentration measured on trap $i, Z_{i}$ is the instrument signal (area counts) for a sample measured on trap $i, Y_{i}$ is the mean calibration factor (instrument signal for the addition divided by the expected concentration) for the additions made on trap $i$ before the flight, $X_{i}$ is the mean calibration factor for the additions made on trap $i$ after the flight, $A$ is the number of each specific measurement ( $A=1$ for the first measurement of the flight), $B$ is the total number of measurements taken during the flight, and $i$ has values of 1 or 2 according to which gold trap the sample was amalgamated on within the Tekran 2537X. This calibration method was used to account for any instrumental drift that may have occurred during this unique inflight deployment. The additions before this particular flight were $7.3 \%$ higher than after the flight; hence the calibration method applied corrected for this drift. Before and after the campaign the internal permeation source was verified using manually injected $\mathrm{Hg}^{0}$ from a temperature-controlled $\mathrm{Hg}$ vapour source at saturation vapour pressure. Recovery from these injections were $98.7 \pm 0.7 \%$. Uncertainty of this system was determined to be $3 \times$ the standard deviation $(3 \sigma)$ of the measurements made in background air $\left(0.054 \mathrm{ng} \mathrm{m}^{-3}\right.$; $n=30)$.

Due to power and space constraints, no atmospheric $\mathrm{Hg}$ speciation measurements could be made on this flight. All references to measurements made by Tekran 2537 series instruments from other studies, either GEM or total gaseous $\mathrm{Hg}$ (TGM $=$ GEM + GOM), will be referred to as GEM for clarity and consistency purposes. As previously described, GOM has not been measured to be elevated above background in wildfire biomass burning emissions (Friedli et al., 2003a; Obrist et al., 2008; Finley et al., 2009; Chen et al., 2013). Thus, any differences between GEM measurements from this study and TGM measurements from other studies based on those studies potentially sampling some GOM are likely to contribute only a minor uncertainty to any data comparisons. All GEM concentrations from this study are reported on a mass-per-volume basis with mixing ratios also reported in parentheses. Conversion calculations of mass per volume to mixing ratio used standard temperature and pressure as the mass flow controller of the Tekran 2537X instrument had already adjusted the mass-per-volume concentrations for the actual temperature and pressure during each measurement cycle.

\subsection{Measurements of other air pollutants}

$\mathrm{CO}, \mathrm{CO}_{2}$, and $\mathrm{CH}_{4}$ were measured with a Picarro G2401-m instrument based on cavity ring-down spectroscopy. Calibrations were performed at the beginning and end of each flight using calibration gas mixtures at two different mixing ratios. The NMOGs were measured with a difference method using two Picarro G2401-m instruments. One instrument sampled through a heated catalyst that converted all the atmospheric $\mathrm{C}$ species, including $\mathrm{CO}_{2}, \mathrm{CO}, \mathrm{CH}_{4}$, and NMOGs to $\mathrm{CO}_{2}$; the second instrument measured $\mathrm{CO}_{2}, \mathrm{CO}$, and $\mathrm{CH}_{4}$ in ambient air (not through the catalyst), and these mixing ratios were used to subtract from the first instrument to obtain a measure of NMOGs. This method was adapted from Stockwell et al. (2018). To allow data comparisons between GEM and these other species that are measured at greater frequency, all $\mathrm{CO}, \mathrm{CO}_{2}, \mathrm{CH}_{4}$, and NMOGs data were synchronised and averaged to the same 2 min sampling resolution of the Tekran $2537 \mathrm{X}$ instrument. The $3 \sigma$ values for $\mathrm{CO}, \mathrm{CO}_{2}, \mathrm{CH}_{4}$, and NMOGs are 12, 380, 4, and $60 \mathrm{ppb}$, respectively, and were calculated using the same approach described for the Tekran 2537X. The instrument uncertainties are similar to those described and outlined in more detail elsewhere (Gordon et al., 2015; Baray et al., 2018; Liggio et al., 2019; Karion et al., 2013).

\subsection{Calculating emissions ratios (ERs)}

Background concentrations of the contaminants are required in certain components of the emissions estimate calculations. For GEM this was determined to be $1.18 \pm 0.02 \mathrm{ng} \mathrm{m}^{-3}$ $\left(1.31 \pm 0.02 \times 10^{-7} \mathrm{ppm}\right)$ during this flight based on the mean measurements made outside the biomass burning plume $(n=30)$. The equivalent background concentration data for the same sampling period for $\mathrm{CO}, \mathrm{CO}_{2}, \mathrm{CH}_{4}$, and NMOGs were $0.134 \pm 0.022,405.2 \pm 1.0,1.906 \pm 0.005$, and $0.107 \pm 0.091 \mathrm{ppm}$, respectively. All ERs (and subsequent EFs and emissions estimates calculations) are based on GEM concentrations that were enhanced by $>1.25 \times$ background GEM concentration $\left(>1.47 \mathrm{ng} \mathrm{m}^{-3}\right.$ ). Data below this fraction were more variable and uncertain and included concentration values below background for some of the reference compounds, particularly for the $\mathrm{CO}_{2}$ enhancements due to the more elevated and variable background concentration of $\mathrm{CO}_{2}$ (Yokelson et al., 2013; Andreae, 2019). In total, 24 GEM concentration measurements were enhanced by $>1.25 \times$ background. Increasing this cut-off value leads to a reduction in data and increased uncertainty in ERs (and EFs and emissions estimates). We believe the data cut-off $>1.25 \times$ GEM background provides appropriate balance between the uncertainties of variable background values and reduced data. A sensitivity analysis of this value is assessed in Sect. S5. Regressions of GEM and the co-emitted pollutants used orthogonal regressions based on the method developed 
by Neri et al. (1989). The ER uncertainty values (slope) were derived from the method described in Reed et al. (1989).

The ER is the slope of the regression of a target species $(X)$ and a reference species $(Y)$, preferably both enhanced in an emissions plume according to Eq. (2) (Jaffe et al., 2005):

$X=\mathrm{ER}_{X Y} \cdot Y$.

Both the $\Delta X: \Delta Y$ (excess mixing ratios, adjusted for background) and $X: Y$ (measured mixing ratios) ratios have been used in previous studies. However, regressions of both relationships generate the same slope. Here we will use the unitless ERs based on the mixing ratios of GEM to $\mathrm{CO}, \mathrm{CO}_{2}$, $\mathrm{CH}_{4}$, and NMOGs unadjusted for background concentrations in order to display the original data.

It is also possible to calculate ERs using an integration method (Urbanski, 2013). ERs using this method for GEM : CO, GEM : $\mathrm{CO}_{2}$, GEM : $\mathrm{CH}_{4}$, and GEM : NMOGs were within $10 \%$ of the regression method - consistent with variability in the literature (Urbanski, 2013). The ERs determined using the regression method (Eq. 2) are used in this study.

It is important that we consider that the ERs calculated from the GEM concentration data do not include any PBM fraction. All our emissions estimates include TAM scenarios of $0 \%, 3.8 \%, 15 \%$, and $30 \% \mathrm{PBM}$, with the remainder being our measured GEM concentrations (no GOM contribution) to cover the range of uncertainty associated with the unmeasured and otherwise uncertain PBM fraction. The $0 \%$ PBM scenario produces GEM emissions estimates based directly on our measured GEM concentration and represents the lowest data uncertainty; these are the data predominantly discussed in this study. The 3.8\% PBM scenario equates to the measured fraction from Friedli et al. (2003b), which represents the most relevant near-source aircraft-based monitoring of $\mathrm{Hg}$ in a wildfire plume and allows direct data comparison between this and their study. The 15 and $30 \%$ are also assessed for model sensitivity purposes and are the assumed fraction and suggested upper limit of the PBM fraction in De Simone et al. (2017), respectively. Adjustments for PBM were achieved by dividing the GEM concentration data by 1 minus the assumed fraction of PBM and then recalculating the regressions between GEM and the other primary pollutants.

\subsection{Calculating emissions factors (EFs)}

EFs (unit mass of $\mathrm{Hg}$ released per unit mass of fuel combusted; grams per kilogram) are also an important component required to estimate $\mathrm{Hg}$ emissions from biomass burning. These can be estimated by either adjusting the measured ERs relative to the more widely known EFs of reference species and each compound's molecular weight (MW; Eq. 3; Andreae and Merlet, 2001; Andreae, 2019),

$\mathrm{EF}_{X}=\mathrm{ER}_{X Y} \cdot \frac{\mathrm{MW}_{X}}{\mathrm{MW}_{Y}} \cdot \mathrm{EF}_{Y}$, or using the measured data based on Eq. (4) (Andreae and Merlet, 2001):

$\mathrm{EF}_{X}=\frac{\Delta X \cdot \mathrm{MW}_{X}}{\left[\left(\Delta \mathrm{CO}+\Delta \mathrm{CO}_{2}+\Delta \mathrm{CH}_{4}+\Delta \mathrm{NMOGs}\right) \cdot \mathrm{MW}_{\mathrm{C}}\right]} \cdot C_{\text {biomass }} \cdot 1000$.

$\mathrm{MW}_{\mathrm{C}}$ is the molecular weight of carbon, and $C_{\text {biomass }}$ is the fraction of carbon in biomass. The latter has been assumed as 0.45 in $\mathrm{Hg}$ biomass burning emissions estimates in boreal/temperate forests, but no uncertainty in this parameter is given (Friedli et al., 2003b). Thurner et al. (2013) report higher carbon contents in boreal needleleaf forests (the majority of species in the burned stands of the GLP are needleleaf) of 0.508 with a "negligible" uncertainty. We will use this value in our emissions estimate calculations with an assumed $5 \%$ uncertainty $(0.508 \pm 0.025)$ for uncertainty propagation purposes.

\subsection{Calculating emissions estimates}

There are a number of methods that can be used to estimate $\mathrm{Hg}$ emissions from this wildfire and potentially upscale this to estimate emissions of $\mathrm{Hg}$ for regional or global boreal forests and even global emissions from all biomass burning sources based on the calculated ERs and EFs. To stay within the scope of our study, we will constrain our emissions estimates to four simpler methods and leave more complex emissions modelling for future studies. The mean burned areas used for upscaling emissions to all boreal forests and for total global biomass burning are $78 \pm 50 \times 10^{4}$ and $3.49 \pm 0.24 \times 10^{6} \mathrm{~km}^{2} \mathrm{yr}^{-1}$, respectively, and were derived using the GFEDv4 model (Randerson et al., 2018), and the data were taken from Giglio et al. (2013) for 1995-2011.

Emissions estimate method 1 (EEM1) is the most basic method and simply takes the estimated global emissions of the three more widely monitored carbon gases described previously $\left(\mathrm{CO}, \mathrm{CO}_{2}\right.$, and $\left.\mathrm{CH}_{4}\right)$ and adjusts these emissions estimates according to the measured ERs in our study. The estimated $\mathrm{CO}, \mathrm{CO}_{2}$, and $\mathrm{CH}_{4}$ emissions taken from the literature are given in Sect. S6 (Table S6.1; Jiang et al., 2017; Shi and Matsunaga, 2017; Worden et al., 2017). This method cannot produce an estimate for the GLP fires monitored in this study.

Emissions estimate method 2 (EEM2) converts a literature-derived EF for a reference compound (see Sect. S7 and Andreae, 2019, for the EF values used) to a $\mathrm{Hg} \mathrm{EF}$ using the molecular weight of each species and the measured ER between GEM and the reference compound based on Eq. (3). The emission estimate $\left(Q_{x}\right)$ is then calculated according to Eq. (5):

$Q_{X}=A \cdot B \cdot F \cdot \mathrm{EF}_{X}$,

where $A$ is the total burned area, $B$ is the fuel load and is assumed to be $2.35 \pm 0.99 \mathrm{~kg} \mathrm{~m}^{-2}$ (mean fuel load burned in all fires in Canada's Boreal Plains, 1959-1999; Amiro et al., 
2001), and $F$ is the fraction of $\mathrm{Hg}$ released and is 1.0 as it is assumed all $\mathrm{Hg}$ is released during the fire (with an assumed 0.05 uncertainty term to this value). EEM2 makes a separate $\mathrm{Hg}$ emissions estimates based on each reference compound used $\left(\mathrm{CO}, \mathrm{CO}_{2}\right.$, and $\left.\mathrm{CH}_{4}\right)$.

Emissions estimate method 3 (EEM3) also uses Eq. (5) and is the same as EEM2 except that the EFs are calculated from the measured data according to Eq. (4). The calculated EFs used in EEM2 and EEM3 are listed in Sect. S7 (Table S7.1).

The final method uses the Top-down Emission Rate Retrieval Algorithm (TERRA) and has been designed to generate emissions data specific to the aircraft measurements that were made in this study (Gordon et al., 2015). As such, it is used to evaluate the emissions estimates for the GLP fires and considered separately to the discussion regarding the assessment of upscaling emissions estimates. TERRA estimates emissions transfer rates (kilograms per hour) through boxes or screens from aircraft measurements using the divergence theorem. Pollutant and wind data are mapped to a virtual screen (only screen 1 of flight), and concentration data interpolated using a simple kriging function. For the time series input into TERRA, the $2 \mathrm{~min}$ and $2 \mathrm{~s}$ data become $1 \mathrm{~s}$ data; each second during these 2 min or $2 \mathrm{~s}$ periods has the same concentration.

In this study, we apply TERRA to the stacked horizontal legs of the flight track on the first screen downwind of the fire. Concentrations of $\mathrm{Hg}$ are extrapolated below the lowest flight altitude using a linear least-squares fit (recommended for ground-based emissions; Gordon et al., 2015) at each horizontal grid square below the lowest flight track in the plume area. Extrapolation below the flight path has been shown to be the main source of uncertainty in TERRA. Two alternate extrapolations were tested: (i) assuming a well-mixed layer (constant concentration) below the flight path and (ii) assuming a background concentration at the surface and linearly decreasing concentrations between the lowest flight track and the surface. There was less than $5 \%$ difference in the resulting emission rates between these three methods of extrapolating data to the surface (we very conservatively estimate the extrapolation uncertainty to be $10 \%$ ).

The highest transect for this screen shows a consistent GEM background concentration along the whole transect. The consistent background concentration of this highest transect indicates it was above the plume. Hence, there are no significant emissions above that point. The GEM concentrations measured during the spiral flown to determine the mixed layer height confirm this.

Although the uncertainty of $32 \mathrm{~Hz}$ wind speed measurements is $\approx 0.4 \mathrm{~m} \mathrm{~s}^{-1}$, when synchronised to lower-frequency $(1 \mathrm{~Hz})$ mixing ratio measurements this uncertainty contributes $<1 \%$ to the overall uncertainty of the emissions transfer rate (Gordon et al., 2015) and likely less at the $2 \mathrm{~min}$ GEM data resolution. The overall emissions transfer uncertainty was conservatively estimated to be $15 \%$ (4\% mea- sured uncertainty from average GEM concentration from screen $1,1 \%$ wind speed and between transect concentration interpolations, and $10 \%$ concentration extrapolation below screen). More details of the uncertainty estimations for TERRA are contained in Gordon et al. (2015) and Liggio et al. (2016).

To produce an emissions estimate for the whole fire using TERRA, the emissions transfer rate was upscaled by two methods: (i) assuming constant emissions transfer rate across the whole burning period and (ii) assuming this was the mean emissions transfer rate $\left(Q R_{x}\right)$ for the day of the flight (25 June) and adjusting emissions from other days and nights by multiplying the emissions rate by the ratio of MODIS satellite fire hotspots observed on those days $\left(n_{i} \mathrm{D}\right)$ or nights $\left(n_{i \mathrm{~N}}\right)$ compared to the number of fire hotspots in the day of 25 June $\left(n_{25}\right)$ (Eq. 6). Equation (6) assumes $6 \mathrm{~h}$ night and $18 \mathrm{~h}$ day of this high latitude location in mid-summer.

$$
\begin{aligned}
Q_{X} & =\left(Q R_{X} \cdot 18\right)+\left(Q R_{X} \cdot\left[n_{1 \mathrm{D}} / n_{25}\right] \cdot 18\right) \\
& \left.+\left(Q R_{X} \cdot\left[n_{1 \mathrm{~N}} / n_{25}\right] \cdot 6\right)\right)+\ldots+\left(Q R_{X} \cdot\left[n_{i \mathrm{D}} / n_{25}\right] \cdot 18\right) \\
& \left.+\left(Q R_{X} \cdot\left[n_{i \mathrm{~N}} / n_{25}\right] \cdot 6\right)\right)
\end{aligned}
$$

We list all data taken from literature with one extra significant digit (where possible) to reduce rounding uncertainty in these calculations. Overall uncertainties of emissions estimates were calculated using uncertainty propagation according to Eq. (7):

$\sigma_{\mathrm{T}}=\left[\sqrt{\left(\frac{\sigma_{a}}{a}\right)^{2}+\left(\frac{\sigma_{b}}{b}\right)^{2}+\ldots+\left(\frac{\sigma_{i}}{i}\right)^{2}}\right] \cdot T$,

where $a, b, \ldots, i$ and $T$ are the estimates for each variable and the total, respectively, and $\sigma_{a}, \sigma_{b}, \ldots, \sigma_{i}$ and $\sigma_{\mathrm{T}}$ are the standard deviations or uncertainty estimates for each variable and the total, respectively. All statistical testing and calculations were performed using OriginPro 2018 (OriginLab).

\section{Results and discussion}

\subsection{Elevated gaseous elemental mercury concentrations}

Measurements taken on board the NRC's Convair 580 research aircraft during the GLP fires showed GEM concentrations elevated above background in all four of the screens of the flight on 25 June 2018 (Figs. 2 and 3). The plume was divided into a north and south plume, whose approximate paths are described by the orange and yellow dotted lines in Fig. 2a, respectively. This was likely caused by shifting overnight winds that changed plume trajectory. While there is the possibility of the north plume being derived from an additional fire source not detected by satellite, analysis of satellite imagery in the days before and after the flight provides no evidence of this (no additional source plumes or burned areas near GLP). Considering all data from the whole flight, the GEM concentration was highly correlated 
with other primary pollutants emitted throughout this flight $-\mathrm{CO}\left(R^{2}=0.983 ; p=1 \times 10^{-105}\right), \mathrm{CO}_{2}\left(R^{2}=0.801 ; p=\right.$ $\left.3 \times 10^{-43}\right), \mathrm{CH}_{4}\left(R^{2}=0.736 ; p=6 \times 10^{-36}\right)$, and NMOGs $\left(R^{2}=0.820 ; p=8 \times 10^{-46}\right)-$ confirming these fires as a primary source of GEM to the atmosphere (Figs. 3a and S4.1). The maximum GEM concentration was measured in the south plume at $2.88 \mathrm{ng} \mathrm{m}^{-3}\left(3.22 \times 10^{-7} \mathrm{ppm}\right)$ and occurred during the second transect of screen 1 at $\approx 280 \mathrm{~m}$ above the ground (710 $\mathrm{m}$ a.s.l.). This represents up to a $2.4 \times$ increase in GEM concentrations inside the biomass burning plume during screen 1 . The maximum GEM concentrations measured for the subsequent screens were always in the south plume and were $2.70,2.36$, and $1.73 \mathrm{ng} \mathrm{m}^{-3}\left(3.19 \times 10^{-7}\right.$, $2.63 \times 10^{-7}$, and $1.93 \times 10^{-7} \mathrm{ppm}$ ), representing enhancements of $2.3,2.0$, and $1.5 \times$ above background for screens $2-4$, respectively.

The two other studies examining GEM concentrations in near-source wildfire plumes using aircraft-measured enhancements of $\approx 1.4$ (Friedli et al., 2003a) and $\approx 6$ (Friedli et al., 2003b) times background, placing the maximum enhancement observed in our study in the middle of those values. The size of the fires is likely to have played an important role in the differing enhancements, and indeed the burned area of fires was 1.7 and $220 \mathrm{~km}^{2}$, respectively (compared to $88.0 \mathrm{~km}^{2}$ for the GLP fires). Additionally, both previous studies appear to have sampled the emissions plumes closer than screen 1 of our flight. The differing distance of measurements from the fire (dilution effect) is another major factor driving the different enhancements between these fires. Other factors that are likely to affect the magnitude of GEM enhancement include extent of area burning and fire intensity (flaming or smouldering, potential change in PBM fraction) during the monitoring period and/or variability in the concentration of $\mathrm{Hg}$ in the biomass of the different tree species being burned. Measurements collected from the ground-based Cape Point monitoring station in South Africa are the only other near-source measurements reported from a wildfire emissions plume ( $23 \mathrm{~km} \mathrm{NNW}$ of the site). This fire burned a very similar area to the GLP fires $\left(\approx 90 \mathrm{~km}^{2}\right)$, and GEM enhancements were $\approx 1.45 \times$ background (Brunke et al., 2001).

\subsection{Emissions ratios}

ERs are based on the assumptions that there is no chemical (reaction) or depositional losses of one or both of the measured contaminants and that there is equivalent and constant dilution (Jaffe et al., 2005; Yokelson et al., 2013). This is a valid assumption for measurements taken in biomass burning emissions plumes near source such as those of our study as negligible atmospheric reactions or deposition will occur for any of the considered species (GEM, $\mathrm{CO}, \mathrm{CO}_{2}$, $\mathrm{CH}_{4}$, or NMOGs). The ER for GEM : CO based on the data with GEM enhancements of $>1.25 \times$ background for the GLP fires displayed in Fig. $3 \mathrm{~b}$ and Table 1 (which equates to $0.83 \pm 0.03 \mathrm{ng} \mathrm{m}^{-3} \mathrm{ppm}^{-1}$ using mass-per-volume concentration for GEM) had the strongest fit of the four carbon contaminants examined, with an $R^{2}$ value of 0.979 . GEM : CO ERs are also the most commonly used in the literature to examine $\mathrm{Hg}$ emissions from biomass burning. Wang et al. (2015) summarised the use of GEM : CO ratios from all biomass burning studies and showed a range from $6.7 \pm 0.4 \times 10^{-8}$ taken by near-source aircraft measurements in the Washington State fires $\left(R^{2}=0.86\right.$; Friedli et al., $2003 b$ ) up to $2.4 \pm 1.0 \times 10^{-7}$ using a commercial aircraft at an unknown distance from non-specific fires $\left(R^{2}=0.54\right.$; Ebinghaus et al., 2007). This places the GEM : CO ER determined in our study (Table 1) near the lower end of this range but $1.3 \times$ higher than the other near-source aircraft measurements taken in the large fires in Washington State. The GEM : CO ER of the other near-source aircraft-based study (northern Ontario fire) was $2.2 \times$ that of our value, suggesting enhanced GEM emissions in the small northern Ontario fire. Our data have the lowest uncertainty of any of the previous studies (Wang et al., 2015), which gives us confidence in our data and this GEM : CO ER.

As previously mentioned, many of the studies that have addressed $\mathrm{Hg}$ in biomass burning are not near-source measurements but rather long-range transport of pollutants from the fire sources to distant receptor sites. For any assessment of ERs and emissions estimates to be valid, the ER of the two emitted species must remain constant even after longrange transport of both contaminants. While $\mathrm{CO}$ has been suggested to have a lifetime of several months (Khalil and Rasmussen, 1984; Yurganov et al., 2005; Turnbull et al., 2006), it can be significantly reduced to as little as $10 \mathrm{~d}$ in summer over continental landmasses (Holloway et al., 2000; Yurganov et al., 2004). Although GEM can be readily oxidised under very specific atmospheric conditions (coastal sites in polar spring; Steffen et al., 2002; conditions not met in the current study), the lifetime of GEM is generally accepted to be $\approx 4-12$ months (Holmes et al., 2010; Horowitz et al., 2017; Saiz-Lopez et al., 2018). This difference in lifetime suggests that CO could be more readily lost from the atmosphere than GEM. Since the majority of biomass burning occurs in summer months, such differences undermine the assumption that the ER will be conserved during long-range transport. This becomes progressively more problematic as the distance between source and receptor sites increases. Consequently, the majority of studies that have estimated GEM : CO ER at large distances from the biomass burning source are likely overestimating GEM : CO ERs, which is the likely explanation for the higher ERs reported in such studies (Wang et al., 2015). Potential differences in atmospheric lifetimes between these two primary biomass burning contaminants have not been critically discussed previously in the literature on $\mathrm{Hg}$ emissions from biomass burning.

Differences in lifetimes of GEM and CO are therefore not the major factor behind the differences in the GEM : CO relationship between the GLP fire and Cape Point wildfires 
(a)

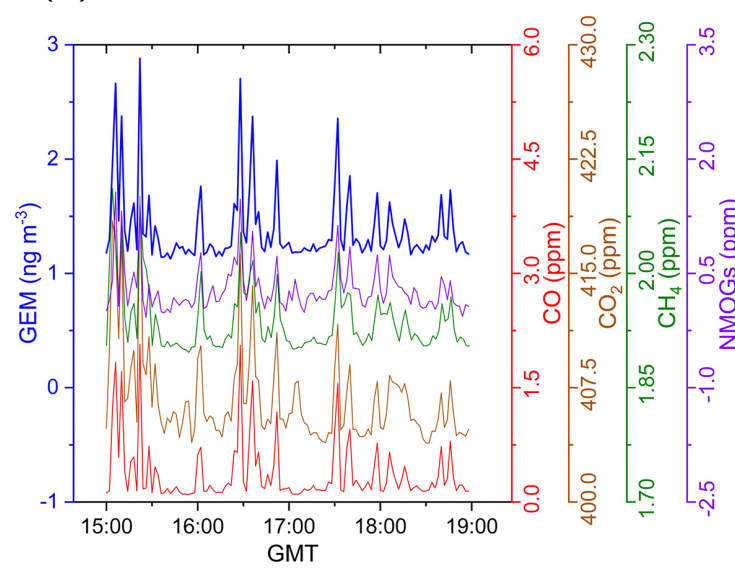

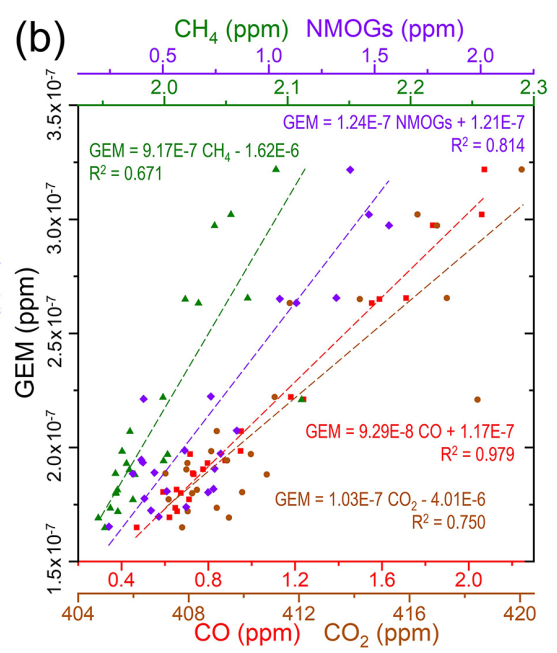

Figure 3. (a) Concentrations of GEM ( 2 min measured) and mixing ratios of $\mathrm{CO}, \mathrm{CO}_{2}, \mathrm{CH}_{4}$, and NMOGs during fire monitoring flight. (b) Mixing ratio orthogonal regressions of GEM against $\mathrm{CO}, \mathrm{CO}_{2}$, and $\mathrm{CH}_{4}$ during the wildfire monitoring flight (these data are based on only the GEM data elevated $>1.25 \times$ the background concentration; $n=24$ ); ERs are derived from the slopes of these regressions. Uncertainty terms for these slopes (ERs) are given in Table 1.

Table 1. Enhancements, ERs, and EFs of GLP fire and the most comparable fires with near-source measurements of GEM.

\begin{tabular}{lllll}
\hline & This study & Brunke et al. (2001) & Friedli et al. (2003a) & Friedli et al. (2003b) \\
\hline Location & NW Saskatchewan, Canada & Cape Point, South Africa & N Ontario, Canada & Washington State, USA \\
\hline Vegetation type & Boreal forest & Fynbos shrubland & Boreal forest & Temperate forest \\
\hline Max measured & $\approx 2.4$ & $\approx 0.45 \times$ & $\approx 0.4 \times$ & $\approx 6 \times$ \\
GEM enhancement & & & & \\
GEM $: \mathrm{CO}$ & $9.29 \pm 0.29 \times 10^{-8}$ & $2.1 \pm 0.2 \times 10^{-7}$ & $2.04 \times 10^{-7^{\mathrm{a}}}$ & $6.7 \pm 0.4 \times 10^{-8}$ \\
$\mathrm{GEM}: \mathrm{CO}_{2}$ & $1.03 \pm 0.13 \times 10^{-8}$ & $1.2 \pm 0.3 \times 10^{-8}$ & $1.49 \pm 0.22 \times 10^{-8}$ & - \\
$\mathrm{CO}: \mathrm{CO}_{2}$ & $0.111 \pm 0.013$ & $0.055 \pm 0.001$ & $0.10 \pm 0.02$ & - \\
GEM $: \mathrm{CH}_{4}$ & $9.2 \pm 1.2 \times 10^{-7}$ & - & - & - \\
GEM : $\left.\mathrm{NMOGs}_{\mathrm{EFs}} \mu \mathrm{g} \mathrm{kg}^{-1}\right)$ & $1.24 \pm 0.12 \times 10^{-7}$ & - & - & - \\
\hline
\end{tabular}

a Value taken from the supplement of Friedli et al. (2009) - no uncertainty given.

${ }^{b}$ Uncertainty of this estimate was recalculated to include their measured $20 \%$ variability in the ratio of $\mathrm{CO}: \mathrm{CO}_{2}$.

All values include one extra significant digit to reduce rounding errors for any subsequent calculations (where possible).

in South Africa, in which the ground-based monitoring station was only $23 \mathrm{~km}$ from the burning source (Brunke et al., 2001). GEM : $\mathrm{CO}_{2}$ ER has also been addressed in other studies, and the GEM : $\mathrm{CO}_{2}$ ER calculated in the GLP fires is slightly lower than the ratio measured by Brunke et al. (2001) in South Africa (Table 1). Brunke et al. (2001) also derived a $\mathrm{CO}: \mathrm{CO}_{2}$ ER of for their fire, which is $\approx 2 \times$ lower than the $\mathrm{CO}: \mathrm{CO}_{2}$ ratio measured in our study (Table 1). Given the GEM : CO ER measured by Brunke et al. (2001) was $2.3 \times$ higher than in our study, it is evident that the CO emissions are either depleted in the South African fire or enhanced in the GLP fire (this study) in relation to both GEM and $\mathrm{CO}_{2}$. Interestingly, $\mathrm{CO}: \mathrm{CO}_{2}$ ERs from both the South African (see Hao et al., 1996; Koppmann et al., 1997) and the GLP (see Friedli et al., 2003a; Simpson et al., 2011) wildfires agree well with the corresponding ratio measured in plumes of fires that burned similar vegetation in their respective regions.

Emissions of $\mathrm{CO}$ can vary relative to other emitted contaminants by fuel type (vegetation), burning stage or intensity, period of the burning season, and meteorology (i.e. temperature and wind speed) (Cofer III et al., 1998; Korontzi et al., 2003; Andreae, 2019). The GLP fires were relatively low intensity, ground-based, smouldering fires, which causes increased emissions of $\mathrm{CO}$ - an incomplete combustion byproduct (Lapina et al., 2008). Variability in the proportion of $\mathrm{CO}$ released from biomass burning is likely a major factor driving the variability of GEM : CO ERs in the literature. Nevertheless, it must also be noted that using $\mathrm{CO}_{2}$ as a reference compound in ERs can also be problematic as the 
fraction of the $\mathrm{CO}_{2}$ enhancement relative to background is less than other contaminants, and $\mathrm{CO}_{2}$ background concentrations are more variable (Yokelson et al., 2013; Andreae, 2019). This explains the greater scatter of data observed for the GEM-CO $\mathrm{CO}_{2}$ regression in the GLP fires $\left(R^{2}=0.750\right.$; Fig. 3).

There may be other primary pollutants that can be used to better comprehend $\mathrm{Hg}$ emissions from biomass burning. $\mathrm{CH}_{4}$ is enhanced in biomass burning plumes, has a long atmospheric lifetime ( $\approx 9$ years; Daniel and Solomon, 1998; Montzka et al., 2011), and varies less than CO based on vegetation type and fire intensity (Cofer III et al., 1998; Korontzi et al., 2003). Nonetheless, the GEM : $\mathrm{CH}_{4}$ ER measured in the GLP fire carries a poorer fit (greater uncertainty; $R^{2}=0.671$ ) than both the GEM : CO and GEM : $\mathrm{CO}_{2}$ ratios (Fig. 3b; Table 1). Similar to $\mathrm{CO}_{2}, \mathrm{CH}_{4}$ is proportionally enhanced in the fire much less than GEM, CO, or NMOGs. Hence, on its own, it does not represent an improved single reference compound in the estimation of $\mathrm{Hg}$ emissions. The fit of the GEM : NMOGs ER $\left(R^{2}=0.814\right)$ was better (lower uncertainty than both GEM : $\mathrm{CH}_{4}$ and GEM : $\mathrm{CO}_{2}$ ERs) and indeed contributed more to the fraction of carbon released from the GLP fires (mean fraction: $9.2 \%$ of the considered elevated data) than $\mathrm{CH}_{4}$ (mean fraction: $1.3 \%$ ). However, this ratio is unlikely to be efficacious at receptor sites distant from burning sources due to the variability in atmospheric lifetimes of the many compounds that make up NMOGs. This study represents the first time GEM : $\mathrm{CH}_{4}$ or GEM : NMOGs ERs have been examined in the literature.

Given the strong linear fit of the regression between GEM and CO mixing ratios (higher $R^{2}$ and lower $p$ value; Fig. 3 ) and the greater proportional enhancement of $\mathrm{CO}$, the GEM : CO ER was used to estimate GEM concentrations at the higher time resolution of the $\mathrm{CO}$ data $(0.5 \mathrm{~Hz})$. The maximum estimated GEM concentration derived was $6.76 \mathrm{ng} \mathrm{m}^{-3}$ $\left(7.55 \times 10^{-7} \mathrm{ppm}\right)$, which represents a $5.6 \times$ enhancement compared to the background GEM concentration (Fig. 4). These data were also used to generate the three-dimensional GEM concentration flight path in Fig. 2a.

McLagan et al. $(2018,2019)$ used power relationships between GEM concentrations and distance from source to estimate the concentrations at ( $1 \mathrm{~m}$ from) point sources. In these studies, passive samplers were used to measure GEM concentrations, which involved longer deployments and provided time-averaged concentrations that were unable to ensure measurements were always downwind of source. Concentrations decreased more rapidly with distance from source than what was observed in the current study (McLagan et al., 2018, 2019). Based on the estimated $0.5 \mathrm{~Hz}$ GEM concentration data from the GLP fires, a logarithmic relationship $\left(R^{2}=0.998\right.$; Fig. 4 b) was used to project GEM concentrations at the wildfire source as it produced a stronger fit than a power relationship $\left(R^{2}=0.976\right)$. The estimated concentrations were $12.9\left(1.44 \times 10^{-6} \mathrm{ppm}\right)$ and $30.0 \mathrm{ng} \mathrm{m}^{-3}$ $\left(3.35 \times 10^{-6} \mathrm{ppm}\right)$ at $1 \mathrm{~km}$ and $1 \mathrm{~m}$ from the fires, respec-

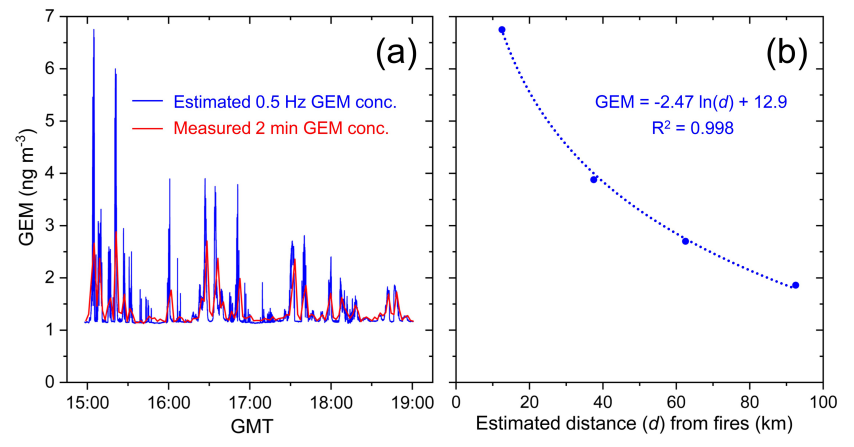

Figure 4. (a) $2 \mathrm{~min}$ measured and $2 \mathrm{~s}$ calculated GEM concentration; the latter was calculated by conversion of the $0.5 \mathrm{~Hz} \mathrm{CO}$ data using the GEM : CO emissions ratio (ER) measured in the GLP fires. (b) The maximum $2 \mathrm{~s}$ calculated GEM concentration derived from GEM : CO ER for each screen and the estimated distance this measurement was from the GLP fires.

tively. This would represent $11 \times$ and $25 \times$ GEM enhancements above background, respectively. While these modelled GEM concentration estimates come with expectedly high uncertainty, they elicit otherwise unattainable information on the GEM concentrations at the active source of these wildfires. Contributing factors to this uncertainty include uncertainties in ER calculation, extrapolation of the logarithmic concentration-distance relationship, uncertainty of exact distances the measurements were made from the fires (wildfires are not a single point source), and variable wind speeds during the sampling period.

\subsection{Mercury emissions estimates}

The emissions estimates for $\mathrm{Hg}$ from biomass burning using EEM1, EEM2, and EEM3 are listed in Table 2. Estimates of GEM emissions from the GLP fires ranged from $13 \pm 8 \mathrm{~kg}$ using EEM2 and $\mathrm{CH}_{4}$ as a reference compound to $21 \pm 10 \mathrm{~kg}$ using EEM3 (Table 2). Differences up to $1.8 \times$ between the GEM emissions estimates for the GLP fires using these two methods demonstrate the increased uncertainty of emissions estimates that arises when assuming literature-based ER data (EEM2) in these calculations. EEM3 is the only method applied here that does not use literature-derived EFs or ERs from reference contaminants to determine $\mathrm{Hg}$ emissions. The only assumed values from the literature applied in EEM3 are the fraction of carbon in the biomass burned that has a low inherent uncertainty (because it has been extensively assessed due to the importance of carbon in biomass and carbon emissions from biomass burning) and the fuel load of the area burned. The latter value does have considerable uncertainty (our value for Canadian Boreal Plains forests has an uncertainty of $42 \%$ ) as it is exceedingly difficult to predict where fires will occur and assay the fuel load of the exact burned stands pre-emptively. Nonetheless, fuel load of area burned is an assumption that must be made in all estimates. Thus, we 
deem the $\mathrm{Hg}$ emissions estimates for the GLP fires to be the most appropriate method contextualised by its $52 \%$ propagated uncertainty, a large factor of which is derived from the assumed fuel load.

Friedli et al. (2003a, b) estimated $\mathrm{Hg}$ emissions using EEM3, albeit with some different assumptions. While we cannot directly compare $\mathrm{Hg}$ emissions from these fires to our emissions estimate of the GLP fires due to differences in burned areas, the aforementioned studies did produce emissions estimates for boreal forests of $59.5 \mathrm{Mg} \mathrm{yr}^{-1}$ (no uncertainty given; Friedli et al., 2003a) and $22 \mathrm{Mg} \mathrm{yr}^{-1}$ (no uncertainty given; Friedli et al., 2003b). The estimate made by Friedli et al. (2003b), which includes their measured $3.8 \%$ PBM fraction, is similar to our EEM3 estimate for boreal forests when we add the same assumed 3.8\% PBM fraction to our GEM data $\left(19 \pm 15 \mathrm{Mg} \mathrm{yr}^{-1}\right)$. The higher emissions estimate made from the small northern Ontario fire (Fiedli et al., 2003a) is likely related to the previously discussed GEM enhancement (relative to $\mathrm{CO}$ and $\mathrm{CO}_{2}$ ) of that particular fire. The EFs of all three studies (Friedli et al., 2003a, b, and our study) are also similar (Table 1). However, an important difference between these studies and the GLP fires is the assumption by Friedli et al. (2003a, b) of a fixed ratio of carbon species in the emissions plume of 10:90:0:0 (CO: $\left.\mathrm{CO}_{2}: \mathrm{CH}_{4}: \mathrm{NMOGs}\right)$. In contrast, the mean ratio of carbon species in the elevated data ( $>1.25 \times$ GEM background) in the GLP fires was $13.0: 76.5: 1.3: 9.2( \pm 3.4: 6.1: 0.4$ : 3.5; $\left.\mathrm{CO}: \mathrm{CO}_{2}: \mathrm{CH}_{4}: \mathrm{NMOGs}\right)$, respectively. If we assume the same 10:90:0:0 ratio of carbon contaminant emissions (derived from our measured $\mathrm{CO}$ concentrations only), the $3.8 \%$ PBM EF becomes $80 \pm 9 \mu \mathrm{gg}^{-1}$ for the GLP fires (see Sect. S7, Table S7.1). This 10:90:0:0 EF is $1.4 \times$ lower than the EFs in either the northern Ontario or Washington State fires, which is similar to the difference in ERs between the GLP $(1.4 \times$ higher $)$ and the Washington State fires.

As Friedli et al. (2003b) report, the EEM3 calculation is highly sensitive to the ratio of carbon species emitted; changes in this ratio, which can be indicative of variable burn intensity (Cofer III et al., 1998), can have an exponential effect on the emissions estimate. This highlights the increased uncertainty associated with the use of a single reference compound and assumed ratios of carbon species emitted in deriving $\mathrm{Hg}$ emissions estimates. Furthermore, the elevated carbon fraction made up by NMOGs in the GLP fires brings into question the assumption that $\mathrm{CO}, \mathrm{CO}_{2}$, and $\mathrm{CH}_{4}$ make up $>95 \%$ of carbon emissions (Fiedli et al., 2003b; Urbanski, 2013), particularly for smouldering fires such as these that can lead to an increased proportion of NMOG emissions (Urbanski, 2013). Recent studies with updated NMOG methods (such as the system used in this study) confirm that NMOGs have been "severely" underestimated in the earlier literature on biomass burning emissions (Andreae, 2019).

Similar to the studies by Friedli et al. (2003a, b), the EF derived from the GLP fires is higher than those measured from laboratory studies (Friedli et al., 2001, 2003a; Obrist et al., 2008). As Friedli et al. (2003a) suggest, this is likely to be caused by the additional $\mathrm{Hg}$ emissions from upper soil layers in the wildfires. Soil components have generally not been included in controlled laboratory burns addressing $\mathrm{Hg}$ biomass burning emissions.

The assumptions of fuel load and biomass carbon fraction are derived from data for boreal forests, and similarly our measurements are of a boreal forest fire. Thus, we suggest our EEM3 estimates to be the most relevant to $\mathrm{Hg}$ emissions from global boreal forests. Even though the EEM1 and EEM2 estimates take data from the literature based on boreal forests, they rely on externally sourced emissions-related data based on an uncertain single reference compound. All the boreal forest emission estimates do, however, have the highest uncertainty of the three emissions scales. This elevated uncertainty is largely associated with the large interannual variability in burned area of boreal forests in North America and Asia (Fraser et al., 2018). The high variability of this estimate must be incorporated into any boreal forest emissions estimate.

Highly constrained global $\mathrm{Hg}$ emissions estimates represent an end goal of research into emissions of $\mathrm{Hg}$ from biomass burning. Nevertheless, global-scale emissions introduce a new set of challenges that are not present when assessing emissions from a single fire or single forest type: chiefly, differences in vegetation type (biome) and meteorology and the associated variability in fire behaviour caused by these differences (Kilgore, 1981; Hély et al., 2001). As stated, the variables used in the EEM3 calculation are tailored to boreal forests; hence, the applicability of this method becomes problematic for global-scale emissions estimates. EEM1 and EEM2 use the measured ER from the GLP boreal forest fires and hence introduce similar concerns associated with upscaling data drawn from a single biome.

The range of estimated $\mathrm{Hg}$ emissions made using the three methods is highly variable and differs by up to a factor of 5.5 (Table 2). While coefficient of variation (values in parenthesis in Table 2) for the global estimates are lower than for the GLP fires or boreal forest fire emissions estimates using single reference compounds (EEM1 and EEM2), the uncertainty of the mean estimate from the three reference compounds does not include the variability between the single reference compound estimates. When this variability is included (mean global EEM1 and EEM2, Table 2), the estimated uncertainty, as expected, increases. Furthermore, the uncertainty terms for the estimates derived from single reference compounds are controlled predominantly by the uncertainties of the literature-derived emissions estimates and EFs for these compounds (which may or may not include fully propagated uncertainties); the uncertainty terms of the measured ERs contribute the least to the estimate uncertainties. It is not possible to determine the additional uncertainty associated with deriving these global $\mathrm{Hg}$ emissions estimates 


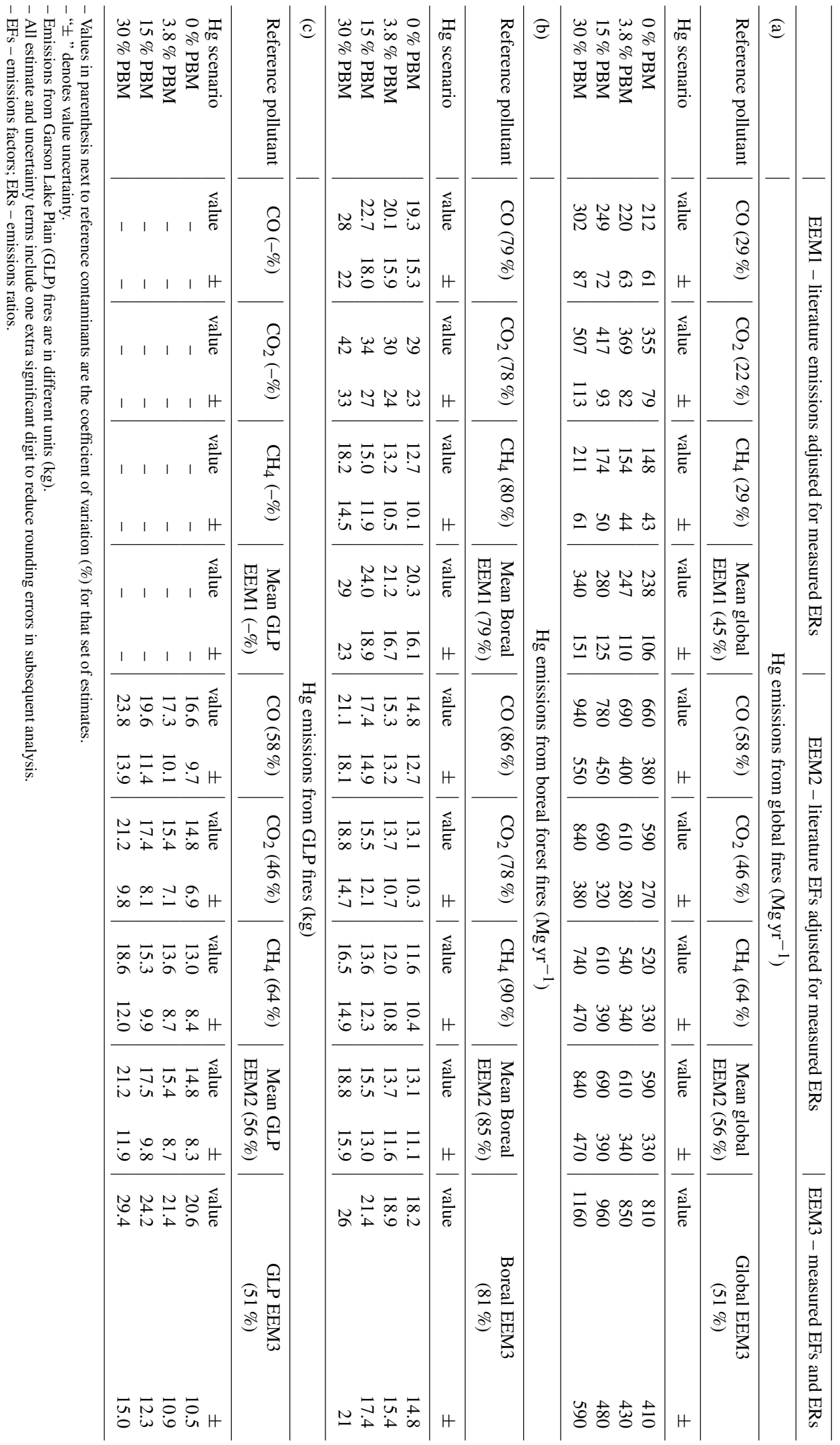

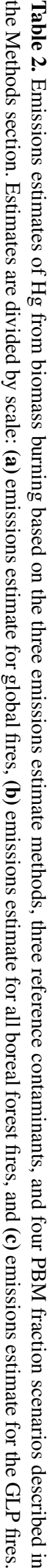


from ERs measured in only one biome, which would likely lead to much higher uncertainties.

The limited availability of atmospheric $\mathrm{Hg}$ (either GEM/TGM or combined GEM, GOM, and PBM) measurements made in biomass burning plumes has also resulted in high uncertainties in emissions estimates made by more complex modelling efforts. Friedli et al. (2009) used biomespecific EFs to estimate global $\mathrm{Hg}$ biomass burning emissions. Yet the EFs specific to each biome were based on highly uncertain soil-based estimates (change in soil $\mathrm{Hg}$ concentration before and after fire); simply "guesses"; or converting ERs (many from sites distant from source) to EFs based on the ratio of these two variables ((GEM: CO ER)/(GEM EF)) in the Washington State fires, which we have shown incorporates elevated uncertainty related to their assumed ratio of carbon contaminant emissions (Friedli et al., 2009). They estimated $675 \pm 240 \mathrm{Mg} \mathrm{yr}^{-1}$ (or between $708-$ $1350 \mathrm{Mg} \mathrm{yr}^{-1}$ based a single non-biome-specific EF scenario) of $\mathrm{Hg}$ emissions from global biomass burning (Friedli et al., 2009). When considering the uncertainty term of this estimate, it would likely be much higher were it to include the fully propagated uncertainty of all these highly uncertain EF values and the assumptions made in their derivation.

A recent effort produced a global TAM (an assumed $15 \%$ PBM fraction was added to the GEM concentrations) emissions estimate of $400 \mathrm{Mg} \mathrm{yr}^{-1}$ (uncertainty described as "large") using a transport and transformation model (De Simone et al., 2017). They also assumed a single TAM : CO ER based on the mean of all studies that have measured $\mathrm{Hg}$ in plumes (De Simone et al., 2017). Their work did highlight the importance of including data inputs from different biomes in a global estimate, be that from either a combined mean value from the different biomes or a value for each biome. At any rate, many of these TAM : CO ERs included in their assessment were measured at receptor sites distant from fire sources, which, as we have discussed, may overestimate this value due to potential difference in the atmospheric residence times of TAM and $\mathrm{CO}$.

An additional uncertainty is the assumed fraction of PBM that we made no measurements of in the GLP fire. All our Hg emissions estimate methods indicate $\mathrm{Hg}$ emissions increase proportionally to the assumed PBM concentration increases (Table 2). However, this is not the case in more complex models that integrate transport and atmospheric chemistry processes. PBM has a much shorter atmospheric lifetime than GEM and deposits much nearer to sources; increasing the PBM fraction leads to greater inputs of $\mathrm{Hg}$ into local and regional terrestrial matrices (De Simone et al., 2017; Fraser et al., 2018). Thus, it is imperative we better constrain our knowledge of $\mathrm{Hg}$ speciation in biomass burning emissions via in-plume measurements of GEM, GOM, and PBM. This has particular importance from a global $\mathrm{Hg}$ biogeochemical cycling standpoint as both De Simone et al. (2017) and Fraser et al. (2018) have shown substantially increased Hg deposition during simulations with elevated PBM inputs (compared to those without PBM emissions) in their global and Canadian transport and fate models, respectively.

\subsection{GLP fire emissions estimate using TERRA}

The GEM concentration screen for screen 1 of the flight generated from the TERRA algorithm and simple kriging interpolation is displayed in Fig. 5. Only the emissions transfer rate of the south plume was considered in the TERRAbased emissions estimates as the concentration data are additive in this algorithm. Including the north plume would overestimate emissions regardless of whether the north plume was derived from a separate undetected fire (i.e. not part of the GLP fire burned area) or resulted from the changing overnight winds (counting emissions from the GLP fires twice). The measured $2 \mathrm{~min}\left(0.77 \pm 0.12 \mathrm{~kg} \mathrm{~h}^{-1}\right)$ and estimated $2 \mathrm{~s}\left(0.67 \pm 10 \mathrm{~kg} \mathrm{~h}^{-1}\right)$ GEM concentration data gave similar results, and the TERRA emissions estimates discussed here are based on the measured 2 min value to allow directly comparable data to the other emissions estimates.

Assuming a constant GEM TERRA-derived emission transfer rate across screen 1 over the whole burning period of the GLP fires $(72 \mathrm{~h})$ gives an emissions estimate of $104 \pm 20.9 \mathrm{~kg}$ of GEM for the GLP fires. Nonetheless, the MODIS satellite imagery shows the fires peaked on the day of the flight (25 June); hence, this assumption creates a large overestimation of the emissions estimate based on the whole fire. To account for changes in the fire intensity, the emissions transfer rate was adjusted by the number of MODIS fire and thermal anomalies observed each day and night (see Sect. S8 for fire and thermal anomaly data), resulting in an improved estimate of $22.0 \pm 6.7 \mathrm{~kg}$ of GEM for the GLP fires, which is remarkably similar to EEM3 $(21 \pm 10 \mathrm{~kg})$. This uncertainty term includes the $26.6 \%$ uncertainty associated with the MODIS satellite fire characterisation (Freeborn et al., 2014). The similarity between the TERRA estimate and the more widely used and largely empirically derived EEM3 estimate for the GLP fires gives weight to the versatility of this algorithm, which has only been previously used to assess industrial pollutant emissions (Gordon et al., 2015; Liggio et al., 2016). Future studies monitoring pollutant emissions from biomass burning using aircraft would benefit from the inclusion of TERRA in their assessment.

\section{Conclusions and recommendations}

This study presents a robust dataset describing elevated GEM concentrations in a near-source biomass burning emissions plume using empirical relationships between GEM and reference contaminants $\left(\mathrm{CO}, \mathrm{CO}_{2}\right.$, and $\left.\mathrm{CH}_{4}\right)$. These data are the most constrained (lowest uncertainty) of any experimental study measuring GEM concentrations and emissions in biomass burning plumes. The measured GEM enhancements, ERs (for multiple reference compounds), and EFs provide a 

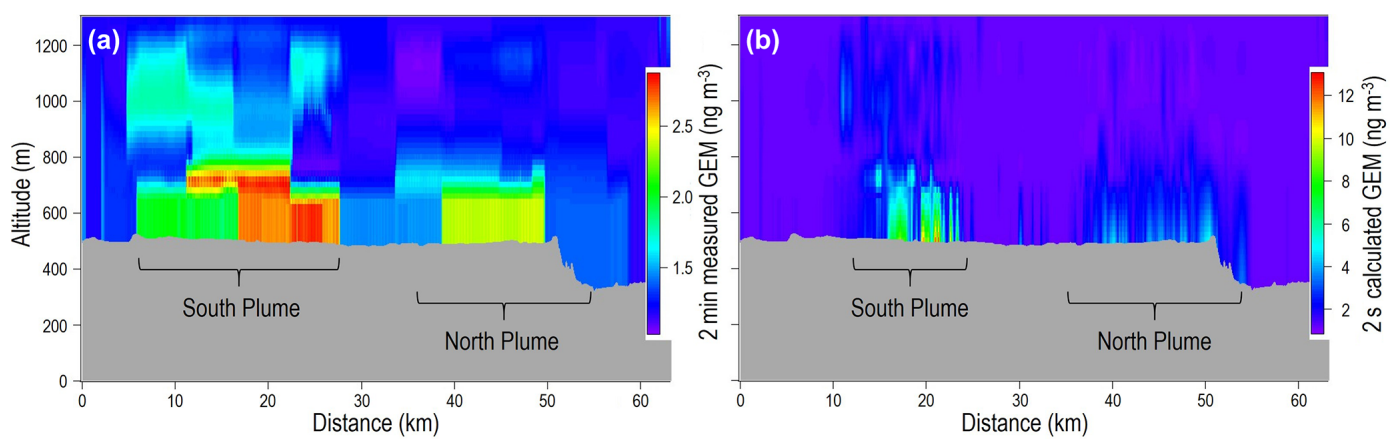

Figure 5. Simple kriging interpolation of TERRA GEM concentration screen for screen 1 of the GLP fires. Panel (a) is based on the 2 min measured GEM concentration data. Panel (b) is based on the $2 \mathrm{~s}$ GEM concentration calculated by conversion of the $0.5 \mathrm{~Hz} \mathrm{CO}$ data using the GEM : CO emissions ratio (ER). Note concentration differences between the $2 \mathrm{~min}$ and $2 \mathrm{~s}$ GEM concentration data in the figure legends.

valuable contribution to the literature on $\mathrm{Hg}$ emissions from biomass burning. We were able to derive a robust GEM emissions estimate of $21 \pm 10 \mathrm{~kg}$ from the GLP fire using the empirically calculated EFs that is well supported by the $22 \pm 7 \mathrm{~kg}$ emissions estimate using the TERRA algorithm. Neither of these estimates require external data inputs (literature values) of reference compounds or extensive assumptions.

Nonetheless, upscaling these emissions to all boreal and global forest fires is inherently problematic, a point we have stressed in detail. The broad range of emissions estimates made for boreal and global forest fires highlights uncertainty associated with factors such as interannual variability in burned area and differing vegetation types. Another major source of uncertainty is the calculation of emissions estimates using data from a single reference compound, a concern that has been somewhat neglected by the atmospheric $\mathrm{Hg}$ community. Typically, Hg ERs or EFs have been based on solely $\mathrm{CO}$ (or occasionally $\mathrm{CO}_{2}$ ) and used to estimate $\mathrm{Hg}$ emissions from biomass burning. These calculations are generally based on very limited empirical data often without a complete description of their uncertainty. We stress potential uncertainty associated with variable $\mathrm{CO}$ enhancements between different fires (vegetation type and fire intensity) and contrasting atmospheric lifetimes of these two contaminants applied in these methods. Similarly, Hg ERs with other potential reference compounds (i.e. $\mathrm{CO}_{2}, \mathrm{CH}_{4}$, and NMOGs) have their own inherent uncertainties.

This does not mean that the Hg ERs should not be used, only that their caveats be fully described and methods be developed to reduce these uncertainties. Help may be on its way; a recent publication attempts to use a statistical modelling approach that combines multiple tracers or reference compounds to predict emissions (Chatfield and Andreae, 2020). Future efforts modelling $\mathrm{Hg}$ emissions from biomass burning are likely to benefit from broader approaches such as this. Additionally, more near-source monitoring of $\mathrm{Hg}$ emissions from biomass burning, particularly using aircraft-based measurements of the different Hg species (GEM, GOM, and
PBM) and carbon co-contaminants $\left(\mathrm{CO}, \mathrm{CO}_{2}\right.$, and $\left.\mathrm{CH}_{4}\right)$, across all biomes would assist in narrowing the uncertainty of Hg-based ERs and potentially produce ERs applicable to vegetation type.

Code availability. All the computer code associated with the TERRA algorithm - including for the kriging of pollutant data, a demonstration dataset, and associated documentation - is freely available upon request. The authors request that future publications which make use of the TERRA algorithm cite Gordon et al. (2015) or Liggio et al. (2016), as appropriate.

Data availability. Full quality-controlled data from all instruments on this flight can be provided upon request.

Supplement. The supplement related to this article is available online at: https://doi.org/10.5194/acp-21-5635-2021-supplement.

Author contributions. DSM was on the flight managing gas measurement instruments, including the Picarro instruments and Tekran 2537X; managed the Tekran 2537X operation and maintenance throughout the monitoring campaign; created Figs. 1-4 and all tables within the paper; managed the calculations of ERs, EFs, and emissions estimates; and wrote the manuscript first draft. GWS was in charge of the technical setup of the Tekran 2537X and ensuring it was fully operational and quality-controlled for aircraft use in the monitoring campaign, assisted with technical difficulties during the monitoring campaign, and contributed to revisions of the manuscript. AD was responsible for the TERRA modelling, created Fig. 5, contributed to Fig. 1, assisted with running the Tekran $2537 \mathrm{X}$ instrument during the monitoring campaign, and contributed to revisions of the manuscript. $\mathrm{KH}$ was project leader of the monitoring campaign; contributed the $\mathrm{CO}, \mathrm{CO}_{2}$, and $\mathrm{CH}_{4}$ data (collection, QA/QC, and analyses); and contributed to revision of the manuscript and ER, EF, and emissions estimate calculations. AS was responsible for overall project planning and management for 
the $\mathrm{Hg}$ component of this project and contributed to revisions of the manuscript.

Competing interests. The authors declare that they have no conflict of interest.

Special issue statement. This article is part of the special issue "Research results from the 14th International Conference on Mercury as a Global Pollutant (ICMGP 2019), MercOx project, and iGOSP and iCUPE projects of ERA-PLANET in support of the Minamata Convention on Mercury (ACP/AMT inter-journal SI)". It is not associated with a conference.

Acknowledgements. The authors would like to acknowledge the entire team of our skilled technicians, ground maintenance staff, pilots, administration, and scientists from the AQRD of ECCC and the NRC working on the monitoring campaign. Special thanks to Richard Mittermeier and John Liggio for their contribution of CO, $\mathrm{CO}_{2}, \mathrm{CH}_{4}$, and NMOG data collection and QA/QC and to ShaoMeng Li and Steward Cober for their tireless work in bringing the aircraft component of the monitoring project to fruition. Additionally, the authors acknowledge the vital data on the wildfire provided by Sindy Nicholson from the Wildfire Management Branch of the Government of Saskatchewan, which, in particular, assisted greatly with the determination of the burned area of the GLP fires. David S. McLagan would like to thank Meinrat O. Andreae from the Max Planck Institute of Chemistry in Mainz, Germany, for his invaluable help ensuring the emissions estimate calculations were correct. David S. McLagan also acknowledges support provided through the National Sciences and Engineering Research Council of Canada (NSERC) Postdoctoral Fellowship Program and his supervisor, Harald Biester, at the Technical University of Braunschweig for allowing time to finalise this project. We also acknowledge the three anonymous reviewers, who gave insightful feedback and suggestions to improve the study.

Financial support. Funding for the study was provided by ECCC.

Review statement. This paper was edited by Aurélien Dommergue and reviewed by three anonymous referees.

\section{References}

Amiro, B. D., Todd, J. B., Wotton, B. M., Logan, K. A., Flannigan, M. D., Stocks, B. J., Mason, J. A., Martell, D. L., and Hirsch, K. G.: Direct carbon emissions from Canadian forest fires, 1959-1999, Can. J. For. Res., 31, 512-525, https://doi.org/10.1139/cjfr-31-3-512, 2001.

Andreae, M. O.: Emission of trace gases and aerosols from biomass burning - an updated assessment, Atmos. Chem. Phys., 19, 8523-8546, https://doi.org/10.5194/acp-19-8523-2019, 2019.
Andreae, M. O. and Merlet, P.: Emission of trace gases and aerosols from biomass burning, Global Biogeochem. Cy., 15, 955-966, https://doi.org/10.1029/2000GB001382, 2001.

Ariya, P. A., Amyot, M., Dastoor, A., Deeds, D., Feinberg, A., Kos, G., Poulain, A., Ryjkov, A., Semeniuk, K., Subir, M., and Toyota, K.: Mercury physicochemical and biogeochemical transformation in the atmosphere and at atmospheric interfaces: A review and future directions, Chem. Rev., 115, 3760-3802, https://doi.org/10.1021/cr500667e, 2015.

Artaxo, P., de Campos, R. C., Fernandes, E. T., Martins, J. V., Xiao, Z., Lindqvist, O., Fernández-Jiménez, M. T., and Maenhaut, W.: Large scale mercury and trace element measurements in the Amazon basin, Atmos. Environ., 34, 4085-4096, https://doi.org/10.1016/S1352-2310(00)00106-0, 2000.

Baray, S., Darlington, A., Gordon, M., Hayden, K. L., Leithead, A., Li, S.-M., Liu, P. S. K., Mittermeier, R. L., Moussa, S. G., O'Brien, J., Staebler, R., Wolde, M., Worthy, D., and McLaren, R.: Quantification of methane sources in the Athabasca Oil Sands Region of Alberta by aircraft mass balance, Atmos. Chem. Phys., 18, 7361-7378, https://doi.org/10.5194/acp-187361-2018, 2018.

Biester, H. and Scholz, C.: Determination of mercury binding forms in contaminated soils: mercury pyrolysis versus sequential extractions, Environ. Sci. Technol., 31, 233-239, https://doi.org/10.1021/es960369h, 1996.

Biswas, A., Blum, J. D., and Keeler, G. J.: Mercury storage in surface soils in a central Washington forest and estimated release during the 2001 Rex Creek Fire, Sci. Total Environ., 404, 129138, https://doi.org/10.1016/j.scitotenv.2008.05.043, 2008.

Brunke, E. G., Labuschagne, C., and Slemr, F.: Gaseous mercury emissions from a fire in the Cape Peninsula, South Africa, during January 2000, Geophys. Res. Lett., 28, 1483-1486, https://doi.org/10.1029/2000GL012193, 2001.

Chatfield, R. B., Vastano, J. A., Li, L., Sachse, G. W., and Connors, V. S.: The Great African Plume from biomass burning: Generalizations from a three-dimensional study of TRACE A carbon monoxide, J. Geophys. Res.-Atmos., 103, 28059-28077, https://doi.org/10.1029/97JD03363, 1998.

Chatfield, R. B., Andreae, M. O., ARCTAS Science Team, and SEAC4RS Science Team: Emissions relationships in western forest fire plumes - Part 1: Reducing the effect of mixing errors on emission factors, Atmos. Meas. Tech., 13, 7069-7096, https://doi.org/10.5194/amt-13-7069-2020, 2020.

Chen, C., Wang, H., Zhang, W., Hu, D., Chen, L., and Wang, X.: High-resolution inventory of mercury emissions from biomass burning in China for 2000-2010 and a projection for 2020, J. Geophys. Res.-Atmos., 118, 248-256, https://doi.org/10.1002/2013JD019734, 2013.

Cofer III, W. R., Winstead, E. L., Stocks, B. J., Goldammer, J. G., and Cahoon, D. R.: Crown fire emissions of $\mathrm{CO}_{2}$, $\mathrm{CO}, \mathrm{H}_{2}, \mathrm{CH}_{4}$, and TNMHC from a dense jack pine boreal forest fire, Geophys. Res. Lett., 25, 3919-3922, https://doi.org/10.1029/1998GL900042, 1998.

Cole, A., Steffen, A., Eckley, C., Narayan, J., Pilote, M., Tordon, R., Graydon, J. A., St. Louis, V. L., Xu, X., and Branfireun, B.: A survey of mercury in air and precipitation across Canada: patterns and trends. Atmos., 5, 635-668, https://doi.org/10.3390/atmos5030635, 2014. 
Daniel, J. S. and Solomon, S.: On the climate forcing of carbon monoxide, J. Geophys. Res.-Atmos., 103, 13249-13260, https://doi.org/10.1029/98JD00822, 1998.

DeBano, L. F.: The role of fire and soil heating on water repellency in wildland environments: a review, J. Hydro., 231, 195-206, https://doi.org/10.1016/S0022-1694(00)00194-3, 2000.

Demers, J. D., Driscoll, C. T., Fahey, T. J., and Yavitt, J. B.: Mercury cycling in litter and soil in different forest types in the Adirondack region, New York, USA, Ecol. Appl., 17, 13411351, https://doi.org/10.1890/06-1697.1, 2007.

Demers, J. D., Blum, J. D., and Zak, D. R.: Mercury isotopes in a forested ecosystem: Implications for air-surface exchange dynamics and the global mercury cycle, Global Biogeochem. Cy., 27, 222-238, https://doi.org/10.1002/gbc.20021, 2013.

De Simone, F., Cinnirella, S., Gencarelli, C. N., Yang, X., Hedgecock, I. M., and Pirrone, N.: Model study of global mercury deposition from biomass burning, Environ. Sci. Technol., 49, 67126721, https://doi.org/10.1021/acs.est.5b00969, 2015.

De Simone, F., Artaxo, P., Bencardino, M., Cinnirella, S., Carbone, F., D’Amore, F., Dommergue, A., Feng, X. B., Gencarelli, C. N., Hedgecock, I. M., Landis, M. S., Sprovieri, F., Suzuki, N., Wängberg, I., and Pirrone, N.: Particulate-phase mercury emissions from biomass burning and impact on resulting deposition: a modelling assessment, Atmos. Chem. Phys., 17, 1881-1899, https://doi.org/10.5194/acp-17-1881-2017, 2017.

Ebinghaus, R., Slemr, F., Brenninkmeijer, C. A. M., Van Velthoven, P., Zahn, A., Hermann, M., O'Sullivan, D. A., and Oram, D. E.: Emissions of gaseous mercury from biomass burning in South America in 2005 observed during CARIBIC flights, Geophys. Res. Lett., 34, L08813, https://doi.org/10.1029/2006GL028866, 2007

ECCC: Daily and hourly Climate Normals, Environment and Climate Change Canada (ECCC), available at: http://climate. weather.gc.ca, last access: 3 September 2019.

Engle, M. A., Gustin, M. S., Johnson, D. W., Murphy, J. F., Miller, W. W., Walker, R. F., Wright, J., and Markee, M.: Mercury distribution in two Sierran forest and one desert sagebrush steppe ecosystems and the effects of fire, Sci. Total Eviron., 367, 222233, https://doi.org/10.1016/j.scitotenv.2005.11.025, 2006.

Finley, B. D., Swartzendruber, P. C., and Jaffe, D. A.: Particulate mercury emissions in regional wildfire plumes observed at the Mount Bachelor Observatory, Atmos. Environ., 43, 6074-6083, https://doi.org/10.1016/j.atmosenv.2009.08.046, 2009.

Fraser, A., Dastoor, A., and Ryjkov, A.: How important is biomass burning in Canada to mercury contamination?, Atmos. Chem. Phys., 18, 7263-7286, https://doi.org/10.5194/acp18-7263-2018, 2018.

Freeborn, P. H., Wooster, M. J., Roy, D. P., and Cochrane, M. A.: Quantification of MODIS fire radiative power (FRP) measurement uncertainty for use in satellite-based active fire characterization and biomass burning estimation, Geophys. Res. Lett., 41, 1988-1994, https://doi.org/10.1002/2013GL059086, 2014.

Friedli, H. R., Radke, L. F., and Lu, J. Y.: Mercury in smoke from biomass fires, Geophys. Res. Lett., 28, 3223-3226, https://doi.org/10.1029/2000GL012704, 2001.

Friedli, H. R., Radke, L. F., Lu, J. Y., Banic, C. M., Leaitch, W. R., and MacPherson, J. I.: Mercury emissions from burning of biomass from temperate North American forests: labora- tory and airborne measurements, Atmos. Environ., 37, 253-267, https://doi.org/10.1016/S1352-2310(02)00819-1, 2003a.

Friedli, H. R., Radke, L. F., Prescott, R., Hobbs, P. V., and Sinha, P.: Mercury emissions from the August 2001 wildfires in Washington State and an agricultural waste fire in Oregon and atmospheric mercury budget estimates, Global Biogeochem. Cy., 17, 1039, https://doi.org/10.1029/2002GB001972, 2003b.

Friedli, H. R., Radke, L. F., Payne, N. J., McRae, D. J., Lynham, T. J., and Blake, T. W.: Mercury in vegetation and organic soil at an upland boreal forest site in Prince Albert National Park, Saskatchewan, Canada, J. Geophys. Res.-Biogeosci., 112, G01004, https://doi.org/10.1029/2005JG000061, 2007.

Friedli, H. R., Arellano, A. F., Cinnirella, S., and Pirrone, N.: Initial estimates of mercury emissions to the atmosphere from global biomass burning, Environ. Sci. Technol., 43, 3507-3513, https://doi.org/10.1021/es802703g, 2009.

Giglio, L., Randerson, J. T., and van der Werf, G. R.: Analysis of daily, monthly, and annual burned area using the fourth-generation global fire emissions database (GFED4), J. Geophys. Res.-Biogeosci., 118, 317-328, https://doi.org/10.1002/jgrg.20042, 2013.

Godbold, D. L. and Hüttermann, A.: Inhibition of photosynthesis and transpiration in relation to mercury-induced root damage in spruce seedlings, Physiol. Plant., 74, 270-275, https://doi.org/10.1111/j.1399-3054.1988.tb00631.x, 1988.

Gordon, M., Li, S.-M., Staebler, R., Darlington, A., Hayden, K., O'Brien, J., and Wolde, M.: Determining air pollutant emission rates based on mass balance using airborne measurement data over the Alberta oil sands operations, Atmos. Meas. Tech., 8, 3745-3765, https://doi.org/10.5194/amt-8-3745-2015, 2015.

Graydon, J. A., St. Louis, V. L., Lindberg, S. E., Hintelmann, H., and Krabbenhoft, D. P.: Investigation of mercury exchange between forest canopy vegetation and the atmosphere using a new dynamic chamber, Environ. Sci. Technol., 40, 4680-4688, https://doi.org/10.1021/es0604616, 2006.

Graydon, J. A., St. Louis, V. L., Hintelmann, H., Lindberg, S. E., Sandilands, K. A., Rudd, J. W., Kelly, C. A., Tate, M. T., Krabbenhoft, D. P., and Lehnherr, I.: Investigation of uptake and retention of atmospheric $\mathrm{Hg}$ (II) by boreal forest plants using stable $\mathrm{Hg}$ isotopes, Environ. Sci. Technol., 43, 4960-4966, https://doi.org/10.1021/es900357s, 2009.

Hao, W. M., Ward, D. E., Olbu, G., and Baker, S. P.: Emissions of $\mathrm{CO}_{2}, \mathrm{CO}$, and hydrocarbons from fires in diverse African savanna ecosystems, J. Geophys. Res.-Atmos., 101, 23577-23584, https://doi.org/10.1029/95JD02198, 1996.

Hély, C., Flannigan, M., Bergeron, Y., and McRae, D.: Role of vegetation and weather on fire behavior in the Canadian mixedwood boreal forest using two fire behavior prediction systems, Can. J. For. Res., 31, 430-441, https://doi.org/10.1139/x00-192, 2001.

Holloway, T., Levy, H., and Kasibhatla, P.: Global distribution of carbon monoxide, J. Geophys. Res.-Atmos., 105, 12123-12147, https://doi.org/10.1029/1999JD901173, 2000.

Holmes, C. D., Jacob, D. J., Corbitt, E. S., Mao, J., Yang, X., Talbot, R., and Slemr, F.: Global atmospheric model for mercury including oxidation by bromine atoms, Atmos. Chem. Phys., 10, 12037-12057, https://doi.org/10.5194/acp-10-120372010, 2010.

Jaffe, D., Prestbo, E., Swartzendruber, P., Weiss-Penzias, P., Kato, S., Takami, A., Hatakeyama, S., and Kajii, Y.: Export of atmo- 
spheric mercury from Asia, Atmos. Environ., 39, 3029-3038, https://doi.org/10.1016/j.atmosenv.2005.01.030, 2005.

Jiang, Z., Worden, J. R., Worden, H., Deeter, M., Jones, D. B. A., Arellano, A. F., and Henze, D. K.: A 15-year record of $\mathrm{CO}$ emissions constrained by MOPITT CO observations, Atmos. Chem. Phys., 17, 4565-4583, https://doi.org/10.5194/acp17-4565-2017, 2017.

Jiskra, M., Wiederhold, J. G., Skyllberg, U., Kronberg, R. M., Hajdas, I., and Kretzschmar, R.: Mercury deposition and reemission pathways in boreal forest soils investigated with $\mathrm{Hg}$ isotope signatures, Environ. Sci. Technol., 49, 7188-7196, https://doi.org/10.1021/acs.est.5b00742, 2015.

Karion, A., Sweeney, C., Wolter, S., Newberger, T., Chen, H., Andrews, A., Kofler, J., Neff, D., and Tans, P.: Long-term greenhouse gas measurements from aircraft, Atmos. Meas. Tech., 6, 511-526, https://doi.org/10.5194/amt-6-511-2013, 2013.

Kilgore, B. M.: Fire in ecosystem distribution and structure: western forests and scrublands, in: Proceedings of the Conference: Fire Regimes and Ecosystem Properties, edited by: Mooney, $\mathrm{H}$. A., Bonnicksen, T. M., and Christensen, N. L., USDA Forest Service, General Technical Report WO-GTR-26, 58-89, available at: https://www.fs.fed.us/rm/pubs/rmrs_gtr292/1981_kilgore.pdf (last access: 1 April 2021), 1981.

Khalil, M. A. K. and Rasmussen, R. A.: Carbon monoxide in the earth's atmosphere: increasing trend, Science, 224, 54-56, https://doi.org/10.1126/science.224.4644.54, 1984.

Koppmann, R., Khedim, A., Rudolph, J., Poppe, D., Andreae, M. O., Helas, G., Welling, M., and Zenker, T.: Emissions of organic trace gases from savanna fires in southern Africa during the 1992 Southern African Fire Atmosphere Research Initiative and their impact on the formation of tropospheric ozone, J. Geophys. Res.Atmos., 102, 18879-18888, https://doi.org/10.1029/97JD00845, 1997.

Korejbo, A. J.: An archaeological survey in the Clearwater River Provincial Park, Saskatchewan: insights into the archaeology of the boreal forest of northwestern Saskatchewan, Master's thesis, Dept. of Archaeology, University of Saskatchewan, 197 pp., available at: http://hdl.handle.net/10388/etd-07192011-172449 (last access: 1 April 2021), 2011.

Korontzi, S., Justice, C. O., and Scholes, R. J.: Influence of timing and spatial extent of savanna fires in southern Africa on atmospheric emissions, J. Arid Environ., 54, 395-404, https://doi.org/10.1006/jare.2002.1098, 2003.

Laacouri, A., Nater, E. A., and Kolka, R. K.: Distribution and uptake dynamics of mercury in leaves of common deciduous tree species in Minnesota, USA, Environ. Sci. Technol., 47, 10462-10470, https://doi.org/10.1021/es401357z, 2013.

Lapina, K., Honrath, R. E., Owen, R. C., Val Martin, M., Hyer, E. J., and Fialho, P.: Late summer changes in burning conditions in the boreal regions and their implications for NOx and CO emissions from boreal fires, J. Geophys. Res.-Atmos., 113, D11304, https://doi.org/10.1029/2007JD009421, 2008.

Liggio, J., Li, S.-M., Hayden, K., Taha, Y. M., Stroud, C., Darlington, A., Drollette, B. D., Gordon, M., Lee, P., Liu, P., Leithead, A., Moussa, S. G., Wang, D., O’Brien, J., Mittermeier, R. L., Brook, J. R., Lu, G., Staebler, R. M., Han, Y., Tokarek, T. W., Osthoff, H. D., Makar, P. A., Zhang, J., Plata, D. L., and Gentner, D. R.: Oil sands operations as a large source of secondary organic aerosols, Nature, 534, 91-94, https://doi.org/10.1038/nature17646, 2016.

Liggio, J., Li, S. M., Staebler, R. M., Hayden, K., Darlington, A., Mittermeier, R. L., O'Brien, J., McLaren, R., Wolde, M., Worthy, D., and Vogel, F.: Measured Canadian oil sands CO 2 emissions are higher than estimates made using internationally recommended methods, Nat. Comm., 10, 1-9, https://doi.org/10.1038/s41467-019-09714-9, 2019.

Lindberg, S. E., Jackson, D. R., Huckabee, J. W., Janzen, S. A., Levin, M. J., and Lund, J. R.: Atmospheric Emission and Plant Uptake of Mercury from Agricultural Soils near the Almadén Mercury Mine, J. Environ. Qual., 8, 572578, https://doi.org/10.2134/jeq1979.00472425000800040026x, 1979.

McLagan, D. S., Hussain, B. A., Huang, H., Lei, Y. D., Wania, F., and Mitchell, C. P.: Identifying and evaluating urban mercury emission sources through passive sampler-based mapping of atmospheric concentrations, Environ. Res. Lett., 13, 074008, https://doi.org/10.1088/1748-9326/aac8e6, 2018.

McLagan, D. S., Monaci, F., Huang, H., Lei, Y. D., Mitchell, C. P., and Wania, F.: Characterization and Quantification of Atmospheric Mercury Sources Using Passive Air Samplers, J. Geophys. Res.-Atmos., 124, 2351-2362, https://doi.org/10.1029/2018JD029373, 2019

Montzka, S. A., Dlugokencky, E. J., and Butler, J. H.: Non$\mathrm{CO}_{2}$ greenhouse gases and climate change, Nature, 476, 43-50, https://doi.org/10.1038/nature10322, 2011.

Mowat, L. D., St. Louis, V. L., Graydon, J. A., and Lehnherr, I.: Influence of forest canopies on the deposition of methylmercury to boreal ecosystem watersheds, Environ. Sci. Technol., 45, 51785185, https://doi.org/10.1021/es104377y, 2011.

NASA: National Aeronautics and Space Administration (NASA) Worldview: Earth Observing System Data and Information System (EOSDIS), available at: https://worldview.earthdata.nasa. gov/, last access: 8 August 2020.

Neri, F., Saitta, G., and Chiofalo, S.: An accurate and straightforward approach to line regression analysis of error-affected experimental data, J. Phys. E Sci. Instrum., 22, 215-217, https://doi.org/10.1088/0022-3735/22/4/002, 1989.

Nesdoly, R. G.: 2017 Forest Management Plan - Volume 1: Background Information Document, MISTIK Management Ltd., ISBN 978-0-9699737-2-0, 313 pp., available at: https://www.mistik.ca/wp-content/uploads/2019-Documents/ FMP_Volume_I.pdf (last access: 1 April 2021), 2017.

Obrist, D.: Mercury distribution across 14 US forests. Part II: Patterns of methyl mercury concentrations and areal mass of total and methyl mercury, Environ. Sci. Technol., 46, 5921-5930, https://doi.org/10.1021/es2045579, 2012.

Obrist, D., Moosmüller, H., Schürmann, R., Chen, L. W. A., and Kreidenweis, S. M.: Particulate-phase and gaseous elemental mercury emissions during biomass combustion: controlling factors and correlation with particulate matter emissions, Environ. Sci. Technol., 42, 721-727, https://doi.org/10.1021/es071279n, 2008.

Randerson, J. T., van der Werf, G. R., Giglio, L., Collatz, G. J., and Kasibhatla, P. S.: Global Fire Emissions Database, Version 4.1 (GFEDv4). ORNL DAAC, Oak Ridge, Tennessee, USA. https://doi.org/10.3334/ORNLDAAC/1293, 2018. 
Rea, A. W., Lindberg, S. E., and Keeler, G. J.: Assessment of dry deposition and foliar leaching of mercury and selected trace elements based on washed foliar and surrogate surfaces, Environ. Sci. Technol., 34, 2418-2425, https://doi.org/10.1021/es991305k, 2000.

Rea, A. W., Lindberg, S. E., and Keeler, G. J.: Dry deposition and foliar leaching of mercury and selected trace elements in deciduous forest throughfall, Atmos. Environ., 35, 3453-3462, https://doi.org/10.1016/S1352-2310(01)00133-9, 2001.

Reed, B. C.: Linear least-squares fits with errors in both coordinates, Am. J. Phys., 57, 642-646, https://doi.org/10.1119/1.15963, 1989.

Saiz-Lopez, A., Sitkiewicz, S. P., Roca-Sanjuán, D., Oliva-Enrich, J. M., Dávalos, J. Z., Notario, R., Jiskra, M., Xu, Y., Wang, F., Thackray, C. P., Sunderland, E. M., Jacob, D. J., Travnikov, O., Cuenvas, C. A., Acuña, U., Rivero, D., Plane, J. M. C., Kinnison, D. E., and Sonke, J. E.: Photoreduction of gaseous oxidized mercury changes global atmospheric mercury speciation, transport and deposition, Nat. Commun., 9, 1-9, https://doi.org/10.1038/s41467-018-07075-3, 2018.

Schwesig, D. and Matzner, E.: Pools and fluxes of mercury and methylmercury in two forested catchments in Germany, Sci. Total Environ., 260, 213-223, https://doi.org/10.1016/S00489697(00)00565-9, 2000.

Shi, Y. and Matsunaga, T.: Temporal comparison of global inventories of $\mathrm{CO} 2$ emissions from biomass burning during 2002-2011 derived from remotely sensed data. Environ, Sci. Poll. Res., 24, 16905-16916, https://doi.org/10.1007/s11356017-9141-z, 2017.

Sigler, J. M., Lee, X., and Munger, W.: Emission and longrange transport of gaseous mercury from a large-scale Canadian boreal forest fire, Environ. Sci. Technol., 37, 4343-4347, https://doi.org/10.1021/es026401r, 2003.

Simpson, I. J., Akagi, S. K., Barletta, B., Blake, N. J., Choi, Y., Diskin, G. S., Fried, A., Fuelberg, H. E., Meinardi, S., Rowland, F. S., Vay, S. A., Weinheimer, A. J., Wennberg, P. O., Wiebring, P., Wisthaler, A., Yang, M., Yokelson, R. J., and Blake, D. R.: Boreal forest fire emissions in fresh Canadian smoke plumes: $\mathrm{C}_{1}-\mathrm{C}_{10}$ volatile organic compounds (VOCs), $\mathrm{CO}_{2}, \mathrm{CO}, \mathrm{NO}_{2}$, $\mathrm{NO}, \mathrm{HCN}$ and $\mathrm{CH}_{3} \mathrm{CN}$, Atmos. Chem. Phys., 11, 6445-6463, https://doi.org/10.5194/acp-11-6445-2011, 2011.

Slemr, F., Weigelt, A., Ebinghaus, R., Bieser, J., Brenninkmeijer, C. A. M., Rauthe-Schöch, A., Hermann, M., Martinsson, B. G., van Velthoven, P., Bönisch, H., Neumaier, M., Zahn, A., and Ziereis, H.: Mercury distribution in the upper troposphere and lowermost stratosphere according to measurements by the IAGOS-CARIBIC observatory: 2014-2016, Atmos. Chem. Phys., 18, 12329-12343, https://doi.org/10.5194/acp-18-123292018, 2018.

Steffen, A., Schroeder, W., Bottenheim, J., Narayan, J., and Fuentes, J. D.: Atmospheric mercury concentrations: measurements and profiles near snow and ice surfaces in the Canadian Arctic during Alert 2000, Atmos. Environ., 36, 2653-2661, https://doi.org/10.1016/S1352-2310(02)00112-7, 2002.

St. Louis, V. L., Rudd, J. W., Kelly, C. A., Hall, B. D., Rolfhus, K. R., Scott, K. J., Lindberg, S. E., and Dong, W.: Importance of the forest canopy to fluxes of methyl mercury and total mercury to boreal ecosystems, Environ. Sci. Technol., 35, 3089-3098, https://doi.org/10.1021/es001924p, 2001.
Stockwell, C. E., Kupc, A., Witkowski, B., Talukdar, R. K., Liu, Y., Selimovic, V., Zarzana, K. J., Sekimoto, K., Warneke, C., Washenfelder, R. A., Yokelson, R. J., Middlebrook, A. M., and Roberts, J. M.: Characterization of a catalyst-based conversion technique to measure total particulate nitrogen and organic carbon and comparison to a particle mass measurement instrument, Atmos. Meas. Tech., 11, 2749-2768, https://doi.org/10.5194/amt-11-2749-2018, 2018.

Thurner, M., Beer, C., Santoro, M., Carvalhais, N., Wutzler, T., Schepaschenko, D., Shvidenko, A., Kompter, E., Ahrens, B., Levick, S. R., and Schmullius, C.: Carbon stock and density of northern boreal and temperate forests, Glob. Ecol. Biogeogr., 23, 297-310, https://doi.org/10.1111/geb.12125, 2013.

Turnbull, J. C., Miller, J. B., Lehman, S. J., Tans, P. P., Sparks, R. J., and Southon, J.: Comparison of ${ }^{14} \mathrm{CO}_{2}, \mathrm{CO}$, and SF6 as tracers for recently added fossil fuel $\mathrm{CO}_{2}$ in the atmosphere and implications for biological $\mathrm{CO}_{2}$ exchange, Geophys. Res. Lett., 33, L01817, https://doi.org/10.1029/2005GL024213, 2006.

Urbanski, S. P.: Combustion efficiency and emission factors for wildfire-season fires in mixed conifer forests of the northern Rocky Mountains, US, Atmos. Chem. Phys., 13, 7241-7262, https://doi.org/10.5194/acp-13-7241-2013, 2013.

Wang, X., Zhang, H., Lin, C. J., Fu, X., Zhang, Y., and Feng, X.: Transboundary transport and deposition of $\mathrm{Hg}$ emission from springtime biomass burning in the IndoChina Peninsula, J. Geophys. Res.-Atmos., 120, 9758-9771, https://doi.org/10.1002/2015JD023525, 2015.

Weiss-Penzias, P., Jaffe, D., Swartzendruber, P., Hafner, W., Chand, D., and Prestbo, E.: Quantifying Asian and biomass burning sources of mercury using the $\mathrm{Hg} / \mathrm{CO}$ ratio in pollution plumes observed at the Mount Bachelor Observatory, Atmos. Environ., 41, 4366-4379, https://doi.org/10.1016/j.atmosenv.2007.01.058, 2007.

Worden, J. R., Bloom, A. A., Pandey, S., Jiang, Z., Worden, H. M., Walker, T. W., Houweling, S., and Röckmann, T.: Reduced biomass burning emissions reconcile conflicting estimates of the post-2006 atmospheric methane budget, Nat. Commun., 8, 1-11, https://doi.org/10.1038/s41467-017-02246-0, 2017.

Yokelson, R. J., Andreae, M. O., and Akagi, S. K.: Pitfalls with the use of enhancement ratios or normalized excess mixing ratios measured in plumes to characterize pollution sources and aging, Atmos. Meas. Tech., 6, 2155-2158, https://doi.org/10.5194/amt6-2155-2013, 2013.

Yuan, W., Sommar, J., Lin, C. J., Wang, X., Li, K., Liu, Y., Zhang, H., Lu, Z., Wu, C., and Feng, X.: Stable isotope evidence shows re-emission of elemental mercury vapor occurring after reductive loss from foliage, Environ. Sci. Technol., 53, 651-660, https://doi.org/10.1021/acs.est.8b04865, 2018.

Yurganov, L. N., Blumenstock, T., Grechko, E. I., Hase, F., Hyer, E. J., Kasischke, E. S., Koike, M., Kondo, Y., Kramer, I., Leung, F.-Y., Mahieu, E., Mellqvist, J., Notholt, J., Novelli, P. C., Rinsland, C. P., Scheel, H. E., Schulz, A., Strandberg, A., Sussmann, R., Tanimoto, H., Velazco, V., Zander, R., and Zhao, Y.: A quantitative assessment of the 1998 carbon monoxide emission anomaly in the Northern Hemisphere based on total column and surface concentration measurements, J. Geophys. Res.-Atmos., 109, D15305, https://doi.org/10.1029/2004JD004559, 2004

Yurganov, L. N., Duchatelet, P., Dzhola, A. V., Edwards, D. P., Hase, F., Kramer, I., Mahieu, E., Mellqvist, J., Notholt, J., Novelli, 
P. C., Rockmann, A., Scheel, H. E., Schneider, M., Schulz, A., Strandberg, A., Sussmann, R., Tanimoto, H., Velazco, V., Drummond, J. R., and Gille, J. C.: Increased Northern Hemispheric carbon monoxide burden in the troposphere in 2002 and 2003 detected from the ground and from space, Atmos. Chem. Phys., 5, 563-573, https://doi.org/10.5194/acp-5-563-2005, 2005. 